\title{
فاعلية تصميم بيئة تدريب فى تنمية مهارات إدارة قواعد البيانات لدى مسئولي وحدات الإحصائ و المعلومات
}

\section{السيد مخمد محمدين حسانين}

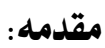

التعليم هو الاستفادة من هذا التقدم وتوظيفــهـ ؛

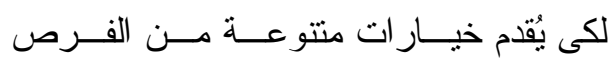

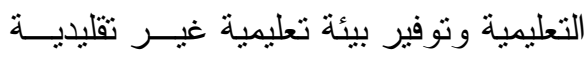

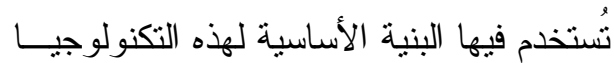
المتقدمة الاستخدام الأمنل. لذا أصبح التعلم الإفتر اضى في الوقت الحاضر ظاهرة و اسعة الانتـشـار، بوصــفة وسيلة تتخطى الحدود الجغر افيــة و الــسياسية

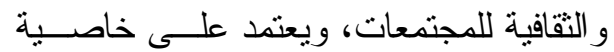

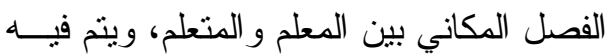
نقل المعرفة إلى المتعلم بدلاً من إحضاره إلى لى

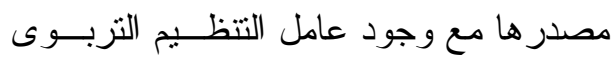

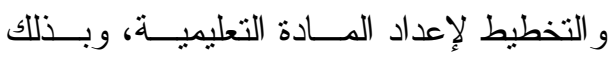

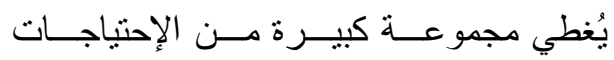

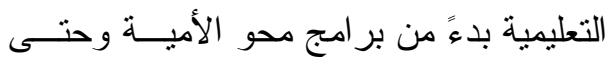

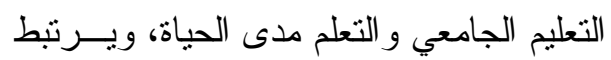

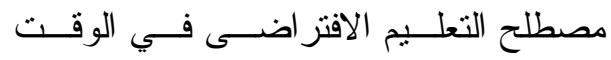

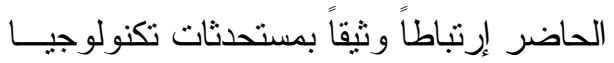

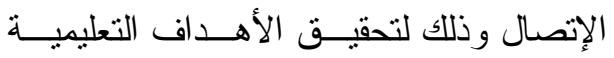

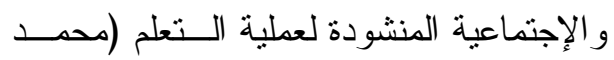

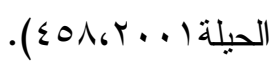

فى ظل النطور المستمر لتكنولوجيــا

الحاسبات، وظهـــور الأنترنـــت و انتــشاره السريع وتتوع ما تقدمه من خدمات منميزة فى توصيل وبــث المعلومسـات ، بحيــث أصبحت أحد أهم مصادر المعلومات ، ومن أهم أدوات الاتصـال الحديثـــة فــى مجــال التعليم عن بعد ، بــــأ اســتخدام الانترنـــت

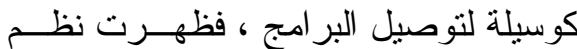

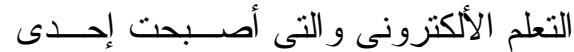
أساليب التعلم عن بعد و التىى أتخذت مكانـــه

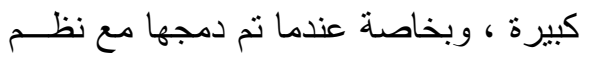

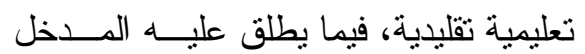
المختلط و الذى يشير إلى أن نظـــام الــتـعلم الأككترونى المستخدم هو إمتــداد للأنــشطة

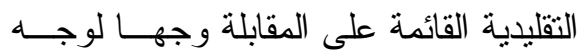

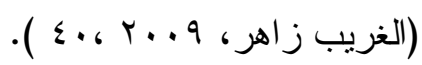
وكان لهذا النطور السريع فى مجال تكنولوجيا المعلومات والاتصالات دور هام فى تغيير طبيعة وشكل المؤسـسـات ومــن بينها المؤسسات التعليمية على نحو جزرى،

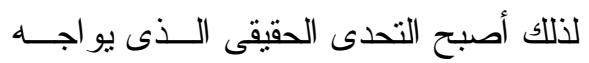


ويتفرع من هذا التساؤل الرئيسي الأســئلة

الفرعية التالية :

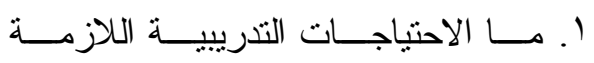

لمسئولى وحدات المعلومات والإحصاء ؟

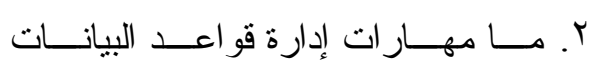

لمسئولى وحدات المعلومات والإحصاء ؟

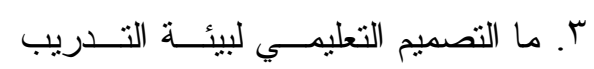

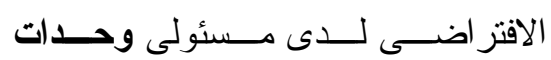

المعلومات والإحصاء؟

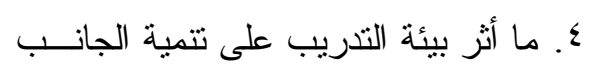

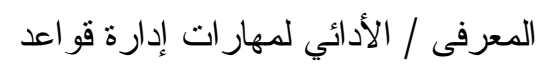

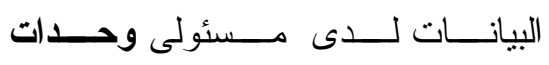

المعلومات والإحصاء ؟ الباء

أهداف البحث: - (أبح:

تسعى الدراسة الحالية إلى تحقيق الأهـــــ التالية :

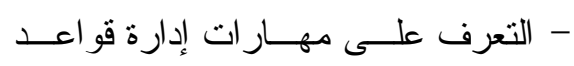

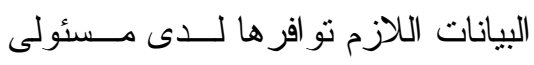

وحدات المعلومات و الإحصاء.

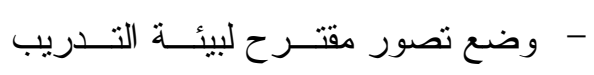

لتتمية مهار ات إدارة قو اعد البيانات لدى لئي

مسئولى وحدات المعلومات و الإحصاء.

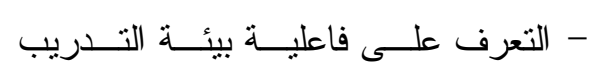

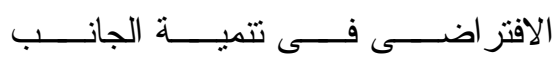

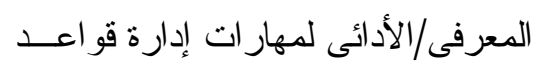

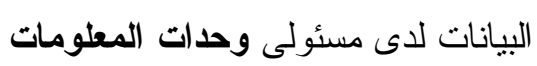

و الإحصاء.

\section{الإحساس بالمكلة:}

لقد نبع الإحساس للباحــث بمـشكلة

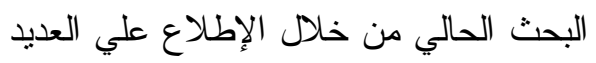

من الدراسات التي تهتم بتدريب المعلمـين الإسين أثناء الخدمة و الدر اسات التي اهتمت بنطبيق تكنولوجيا التعليم في العملية التعليمية وأيضا الار اسات التي تهتم بتتمية مهار ات المعلمين في تشغيل و استخدام التكنولوجيا. فقد أكدت العديد من الدراسات مزايا

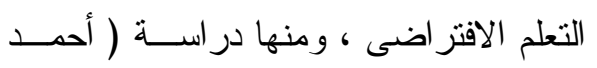

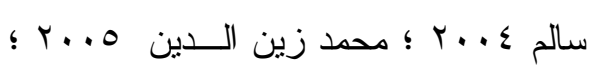

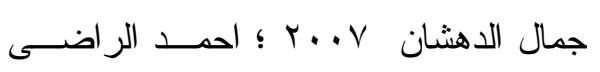

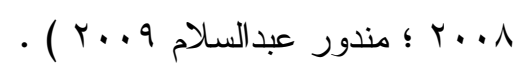
كما تتاولت العديد مــن الدراســات أهمية نتمية مهار ات التدريب فــي البيئـات

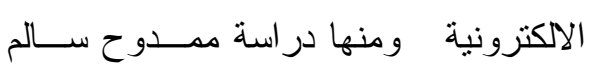

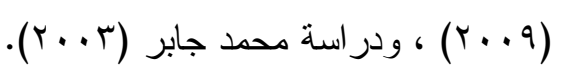
مشكلة البحث: في ضو ء ما سبق تتحـدد مـشكلة

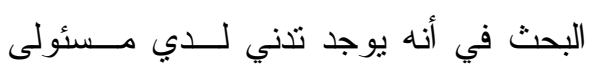
وحدات الإحصاء و المعلومات، في مهار ات لاتئي

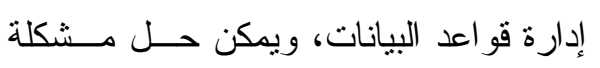

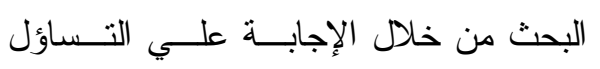
الرئيس التالي:

ما فعالية بيئة التـــريب علــى تنميــة مهارات إدارة قواعد البيانات لاى مسئولي لئه وحدات المعلومات والإحصاء بالمدارس ؟ الدان 
أفر اد المجمو عة التجريبية الأولى (بيئــة تدريب تقليدية) ومتوسط كـسب أفـــر اد

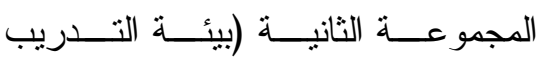
الافتز اضى) في النطبيق البعدي للاختبار

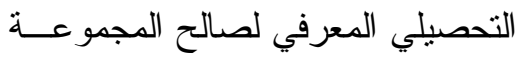
التجريبية الثانية.

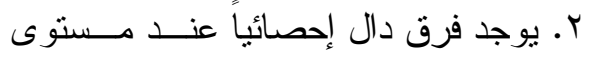

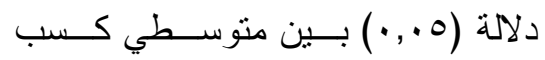
أفر اد المجمو عة التجريبية الأولى (بيئـــة

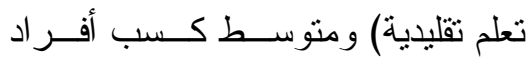

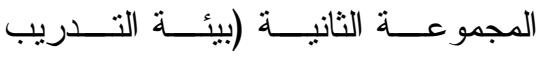
الافتر اضى) في التطبيق البعدي لبطاقـــة

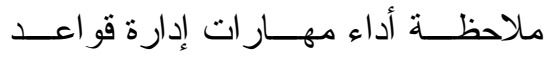
البيانات لصالح المجموعــة التجريييــة

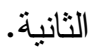
r. تحقق بيئة التدريب الافتز اضــى تـأثنير أكبر في تتمية التحصيل المعرفي.

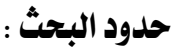

اقتصر هذا البحث على الحدود التالية : ا ـ عينة عشو ائية مــن مسسئولي وحسـدات

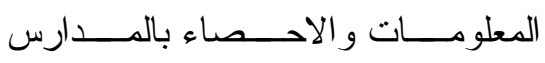
بمديرية التربية و التعليم بالدقهلية عددها r. مهار ات إدارة قو اعد البيانات للى العينة

$$
\text { موضع البحث. }
$$$$
\text { r. بيئة التدريب الإفتر اضى. }
$$

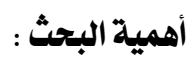

$$
\begin{aligned}
& \text { تنبع أهمية البحث الحالي فيما يلي : }
\end{aligned}
$$

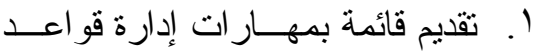

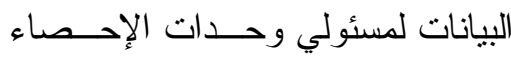

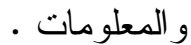

r. تقديم نموذج مقترح لبيئــة التــدريب

الافتر اضى لتتمية مهار ات إدارة قو اعد ليد

البيانات لدى مسئولي وحدات الإحصاء

$$
\text { و المعلومات }
$$

r. يُساهم هذا البحث في توظيف بيئـات

التعلم و التدريب المختلفة فى البيئـات

$$
\text { الإفتر اضية. }
$$

ع. يُعتبر هذا البحث استجابة للاتجاهــات

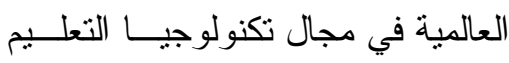

بضرورة الإستفادة مــن المسـتحدثات

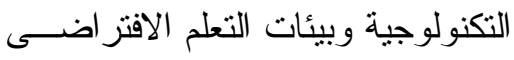

$$
\text { الحديثة. }
$$

○. يساهم البحث فــي تتميــة التحــصيل

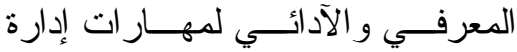

قو اعد البيانات لدى مسئولي وحسـدات

الإحصاء و المعلومات بمديرية التزبية

$$
\text { و التعليم بالدقهلية . }
$$

سعى البحث الحالي للتحة نـق مــن صـــة الفروض التالية :

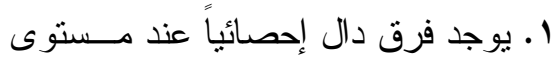

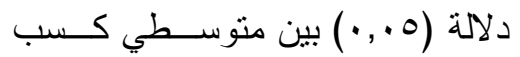


ب - الجانب الأدائسي لمهــار ات إدارة قو اعد البيانات.

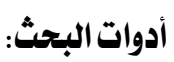

ا. اختبار تحــصيلي إلكترونــي معرفـي الدي

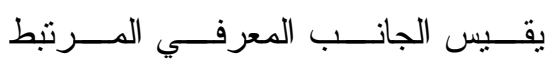

بمهار ات إدارة قو اعد البيانات لدى عينة

$$
\text { الار اسة. }
$$

r. بطاقة ملاحظة لقياس الجانــب الآدائـي

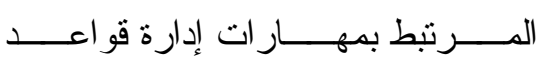

إجرائات البحث:

سوف يتبع الباحث الخطوات التالية :

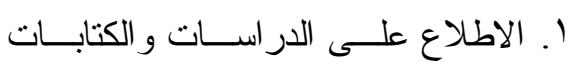

العربية و الأجنبية ذات الصلة بموضوع الاطو

$$
\text { البحث. }
$$

Y. اشثقاق بطاقة تقدير احتياجات مـسئولى

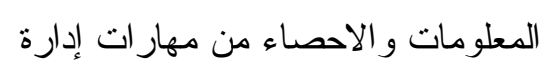

قو اعد البيانات ثم عرضها على مجموعة الاحماء من دهارل

$$
\text { من الخبر اء و المتخصصين. }
$$

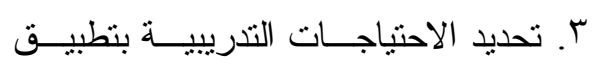

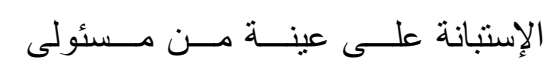

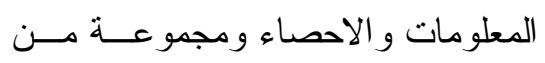

$$
\text { الخبر اء و المتخصصين. }
$$

ع. اشثتقاق قائمة بالمعايير التصميمية لبيئــة

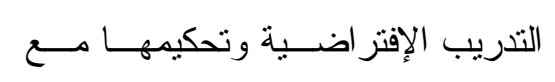

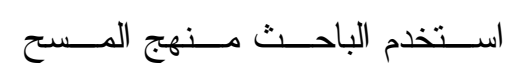

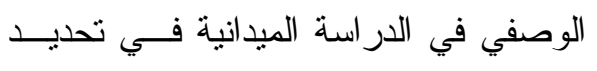

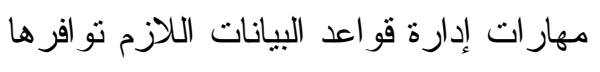
لاى مسئولي وحدات الإحصاء و المعلومات ،و أيضاً وصف وتحليل الأدبيات ذات الصلة بمشكلة البحــث ، كمــا اســتخدم المــــهج التجريبي للتعرف على فاعلية بيئة التدريب

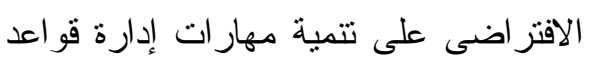
البيانات لدى العينة. التصميم التجريبي: في ضوء طبيعة هذا البحــث وقـــع اختبار الباحث على التصميم التجريبـي ذو ذو لته

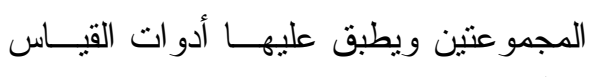

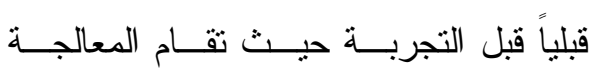
التجريبية للمجموعة التجريبية ( بيئة ندريب تقليدية) و المجموعة الثانية ( بيئـة تــدريب افتر اضية) وبعدالانتهاء من التجربة تطبــق أنق أدو ات القياس بعدياً للمجمو عتين. متغيرات البحث : اثتنمل البحث الحالي علــى المتغيــــات التالية: - الفئل

1- المتغير المسـتقل : بيئــة التـدريب الإفتز اضى المقترحة.

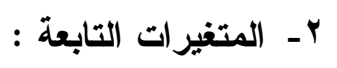
أ - الجانب المعرفــي لمهــار ات إدارة قو اعد البيانات . 


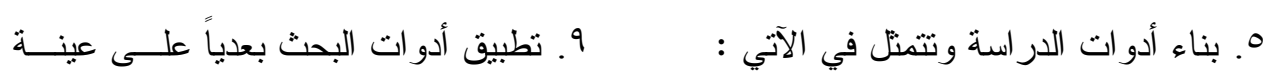

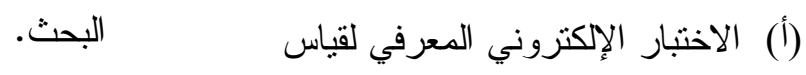

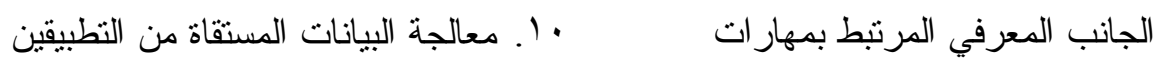

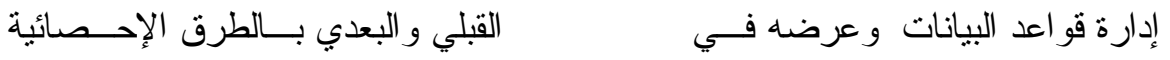

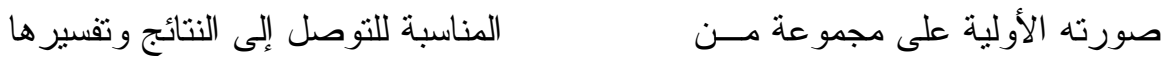

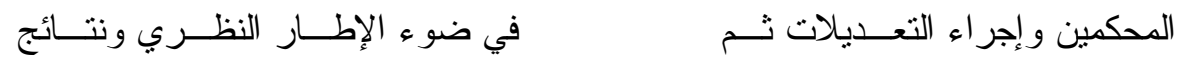

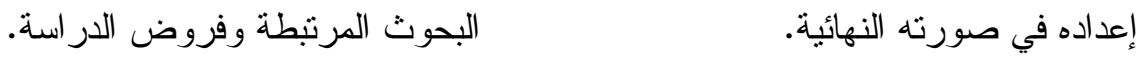

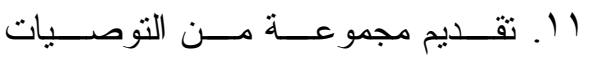

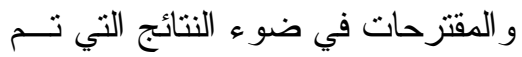

$$
\begin{aligned}
& \text { التوصل إليها . }
\end{aligned}
$$

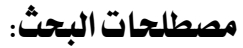

$$
\begin{aligned}
& \text { بيئات التدريب الإفتر اضية : } \\
& \text { هى بيئات الكترونية تتيح التو اصـلـل } \\
& \text { بشكل متز امن و غير منز امن من خلال أدوات } \\
& \text { أكثر فاعلية تنتاسب مع طبيعة الجيل النـانى منى منير } \\
& \text { للتعلم الالكترونى وتمكن المتندرب من نـشـر } \\
& \text { المحتوى التدريبى ووضع الأنشطة و المهـــام }
\end{aligned}
$$

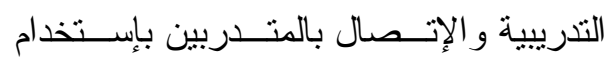

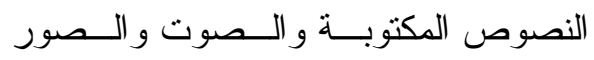

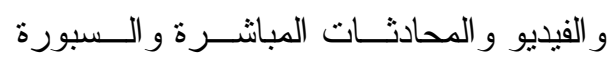

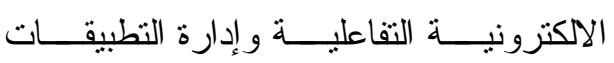

$$
\begin{aligned}
& \text { و الملفات ونقل الملفات وتحقيق الإدارة الفعالة }
\end{aligned}
$$

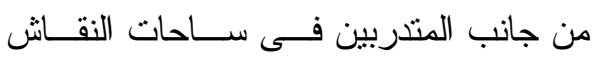

$$
\begin{aligned}
& \text { و الحو ار (Parker\&Martin,2010,136). } \\
& \text { الإطار النظري } \\
& \text { تُعدُّ تكنولوجيا المعلومات والإتصالات } \\
& \text { (ب)بطاقات ملاحظة لقـــاس الجانـبـ } \\
& \text { الأدائي المـــنبط بمهــار ات إدارة }
\end{aligned}
$$

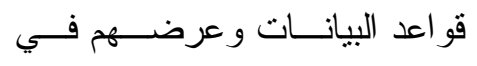

$$
\begin{aligned}
& \text { صورتهم الأولية على مجموعة من } \\
& \text { المحكمين و إجر اء التعـديلات ثــم } \\
& \text { إعداده في صورته النهائية. } \\
& \text { (ج) اختيار أعضاء العينة الاستطلاعية }
\end{aligned}
$$

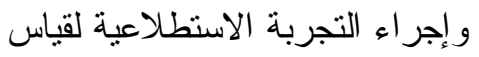

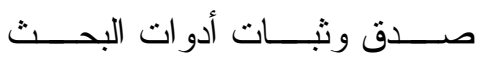

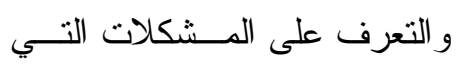

$$
\begin{aligned}
& \text { ستو اجه الباحث أثناء التطبيق. }
\end{aligned}
$$

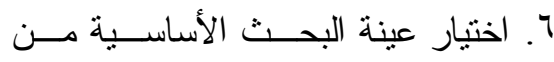

$$
\begin{aligned}
& \text { مسئولي وحدات الإحصاء و المعلومات } \\
& \text { بالمدارس. }
\end{aligned}
$$

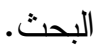

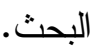


ومدربين معاً من خلال بيئة تعلم تحتوى على

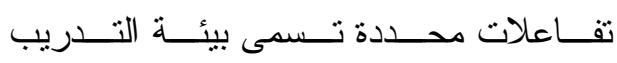
الإلكترونية.

ويُعرف التدريب الإفتر اضــى بأنـــه

عملية تستهدف تقديم البرامج التدريبية عبــر الويب سو اء النمط المتز امن أو الغير متز امن

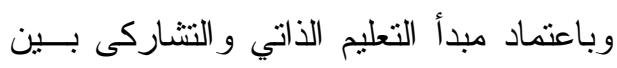
المتعلمين لتوصيل المحتوى وتحقيق الأهداف

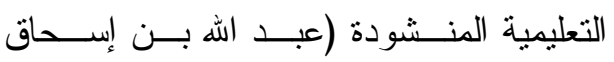

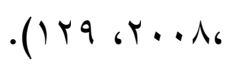

1- أهداف التدريب في البيئات الإفتر اضية: ويُعد تحديد الهدف من التدريب مـن

أهم العمليات التى يقوم عليها التذريب بــصفة

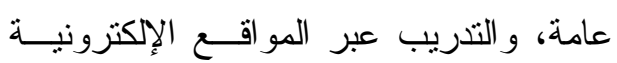
بصفة خاصة ، لأن الهدف إذا تم تحديده بدقة

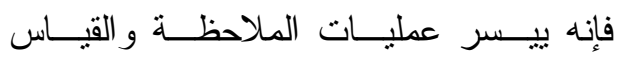
و التقويم.

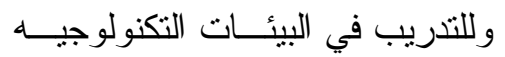

عامة و الافتز اضية بصفة خاصة أهداف بنطلع

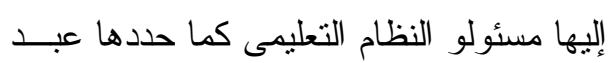

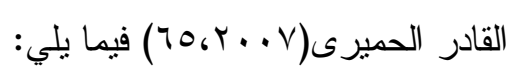

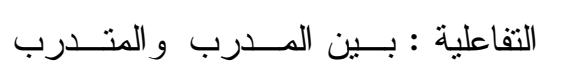

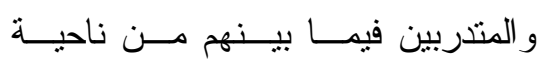

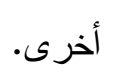

ذاتية التعلم :إذ يمكـن للمتــدربين أن أن إنهان

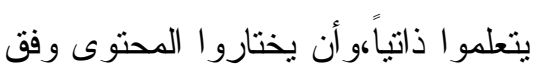

المستمر ، وذللك نتيجة التطور الحـادث فـي

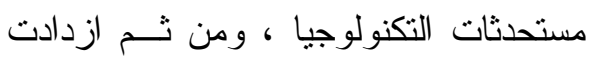
الحاجة في التعليم بضرورة مو اكبة النطور

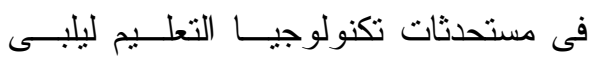

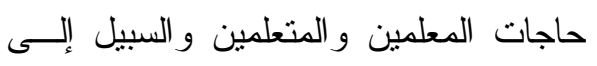

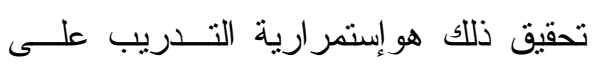

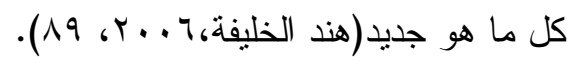
التدريب الإفتر اضى يُعد اســتخداماً

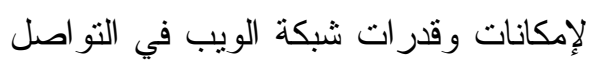
بين المتدربين ومدربيهم في إطار برنــامج

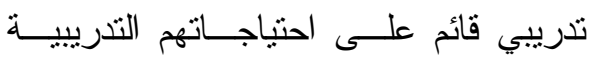
الفعلية، وذللك لتتمية مهار اتهم المتجددة، مع لتع توفير حرية إختيار المحتوى ووقت ومكان التدريب ووسائل الإتصال المختلفة. ويرتكز التدريب الإفتراضى علـى لئى

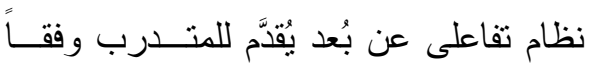

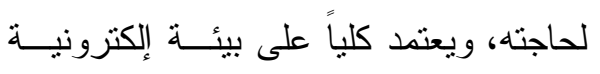

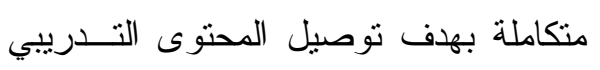
عبر الويب مع نوفير أوجه التغذية الراجعة

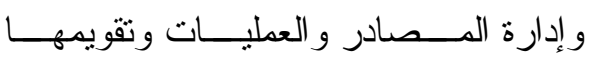

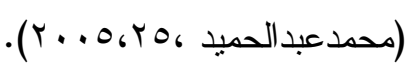

كما تحدد ورقة العمل المقدمة مـن "جريج ويب"(Greg.w(2007,38) و التــي

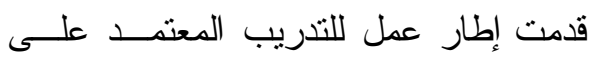
الويب بأنه نمط التدريب الذي يتم من خلال

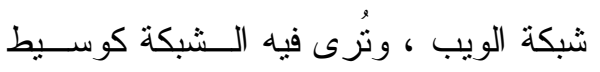

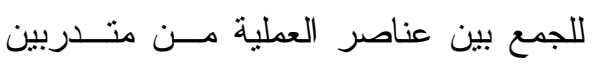




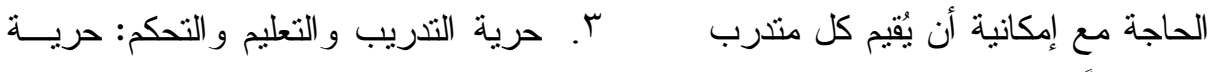

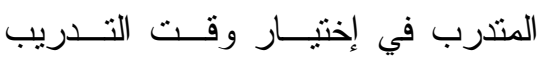

$$
\begin{aligned}
& \text { المناسب لله ومن أبي مكان يريد، وتؤكد }
\end{aligned}
$$

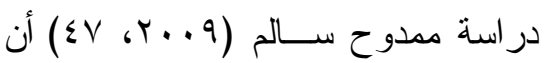

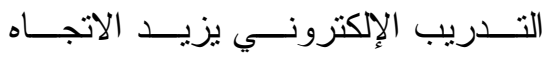

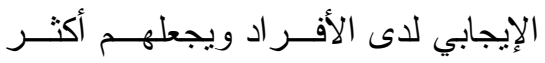

$$
\begin{aligned}
& \text { تحملاً للمسئولية، أكثر قدرة على التوجيه }
\end{aligned}
$$

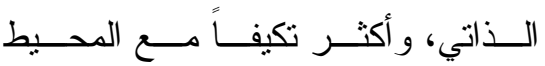

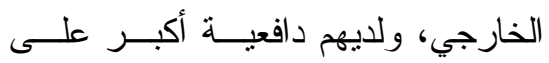

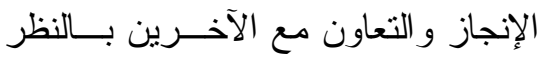

$$
\begin{aligned}
& \text { إلىى الأفر ادالأقل تحملا للمسئولية، وأقــلـل } \\
& \text { تكيفاً مع المحيط الخارجي، و السلبية في } \\
& \text { التعامل مع الآخرين. } \\
& \text { ع. الاستـــرار : حيــث يؤكــــ "بيرجــر" }
\end{aligned}
$$

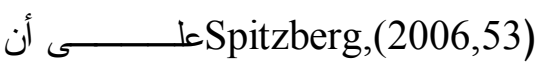

$$
\begin{aligned}
& \text { التنريب الإلكترونى بو اسطة الإنترنــت } \\
& \text { جعل استمر ارية شبه دائمة للتدريب. }
\end{aligned}
$$

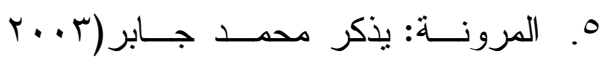

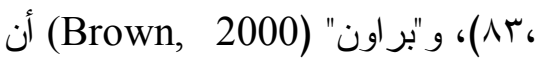

$$
\begin{aligned}
& \text { مرونة التدريب تعنى إتاحسـة التـدريب } \\
& \text { للمتدربين في أي وقت و أى مكان حسب لنب }
\end{aligned}
$$

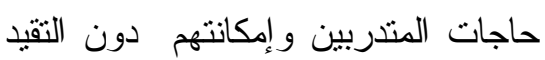

$$
\begin{aligned}
& \text { بوقت محدد، أو مكان معين للتدريب. } \\
& \text { 7. توفير الوقت وخفض التكلفة: أن التدريب } \\
& \text { الإفتز اضى يعمل على الإســتفادة مـنـ } \\
& \text { الوقت عن طريــق إختـــار المحتــوى } \\
& \text { المناسب فقط للمت لـدرب وفــق رغباتـــــ } \\
& \text { نفسه ذاتياً. } \\
& \text { • إمكانية التعلم التعاوني و التـشاركى: } \\
& \text { حيث يتاح للمتعلمين إمكانية النو اصل }
\end{aligned}
$$

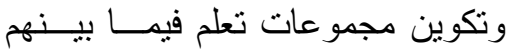

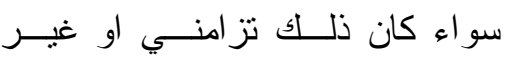

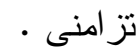

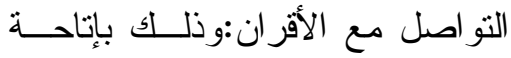

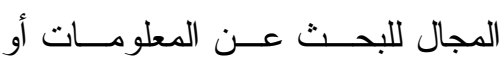

$$
\begin{aligned}
& \text { الإبحار في قو اعد البيانات المعلوماتية }
\end{aligned}
$$

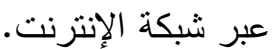

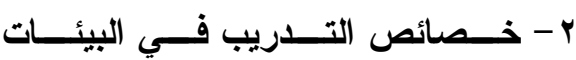

$$
\begin{aligned}
& \text { الإفتر اضية: } \\
& \text { يتميز التدريب الإفتر اضى بالعديــــ } \\
& \text { من الإيجابيات، عن نظم التدريب التقليدية ، } \\
& \text { حيث أن استخدام التدريب الإفتز اضى فـي لـي }
\end{aligned}
$$

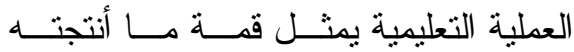

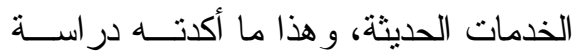

$$
\begin{aligned}
& \text { "الخان" (Khan, 2001) ومن أهــم هـــهـ } \\
& \text { المميز ات ما يلي: } \\
& \text { 1. التفاعـلـنقام أنماط التفاعل في عــدة } \\
& \text { أنثكال بين المتدرب و المدرب و بــين }
\end{aligned}
$$

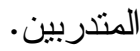

$$
\begin{aligned}
& \text { r. الثمول و التكامل : يقصد بها تكامــل } \\
& \text { جميع مكونات وعناصر التدريب مــع } \\
& \text { بعضها البعض. }
\end{aligned}
$$




$$
\text { عبر الويب، ويحقق تفاعل المندرب مع }
$$
عناصر المحتوى بالبرنامج.

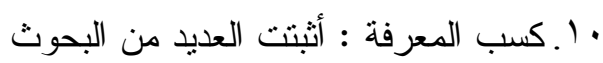

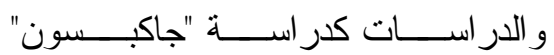
(Jacobson,2005) و ودر اسة "روجــر

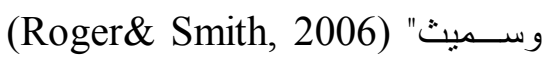
على فاعلية التدريب الإفتر اضــى فــي

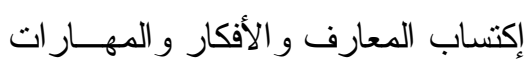
التي تؤدى الى رفع كفاءة المتذربين.

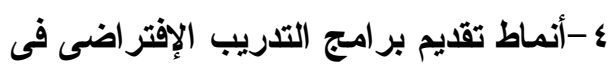
التعليم:

نظر التعدد الأدو ات و الخدمات التـي

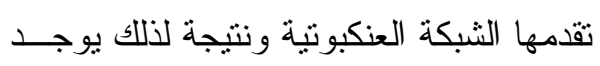

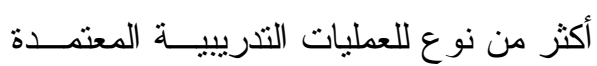

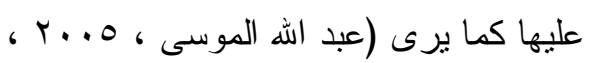

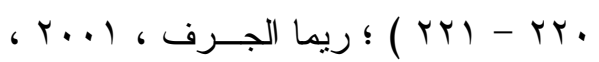
191 ( ) ) حيث تقدم هذه البر امج عبر الويــب، وقد أثنارت الأدبيات إلى وجود نوعين مـنن التدريب بو اسطة الإنترنت وهمـــا: تــدريب بمساعدة الويب يستخدم فيه الانترنت كعامــل مساعد لأثز اء بيئة التذريب حيث بــتم دمـــج مستحدثات شبكة الويب في العملية التدريبيــة و هو ما يسمى التذريب المخــلط وتــدريب معتمد كلياً على شبكة الويب ، فــي بئــات

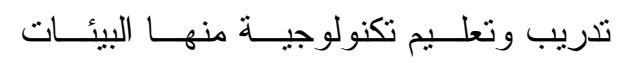

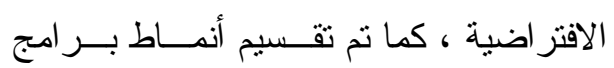
التذريب الالكترونية التي تقدم عبــر شــبكة

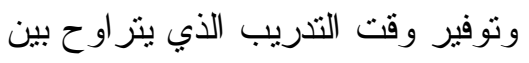

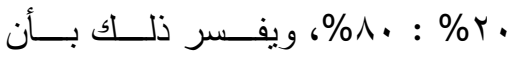

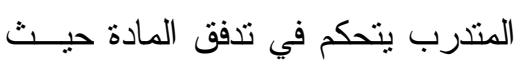
يمكنه تخطى الأجز اء غير الضرورية

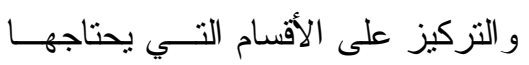
فقط. V. عالمية التدريب:جعل الإنترنت بيئـات تدريب على المـستوى العــالمى بــلا جدر ان. ^. سر عة التدريب: تز امن الوصول لمادة التدريب إلى جميع المتدربين في الوقت نفسه، وكذللك السرعة المناســبة فــي لئي

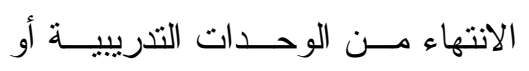
موضوعات ومجالات التنريب (الخطو الذاتي)، هذا إلى جانــب أن التــدريب الإلكتروني يتيح التقييم السريع.

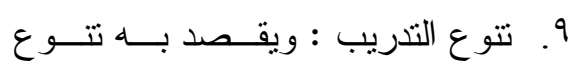
الوسائط و الأدو ات الخاصة بالتفاعـلــل في بر امج التدريب، حيث تُقام بــر امج المانج التدريب الإفتز اضى من خلال وسائط

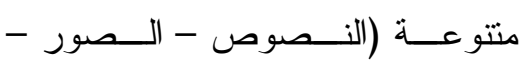
الأصوات - الفيديو - الرسوم الثابتـــة

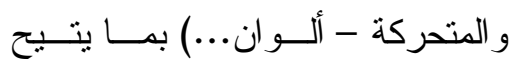
للمتعلم التحكم في عرضها و التفاعـلـل

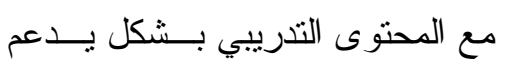

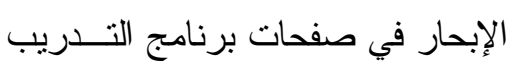




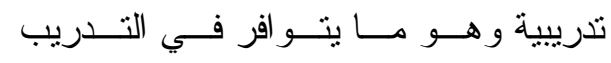

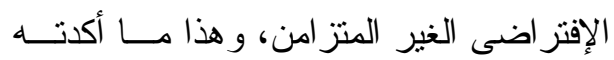

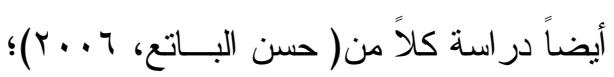
ودر اسة "دافيد" (David,2002).

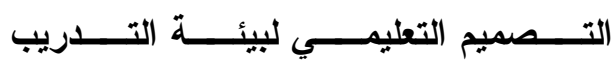
الافتر اضى (*):

لقد تعددت وتتوعت نمــاذج التـصميم

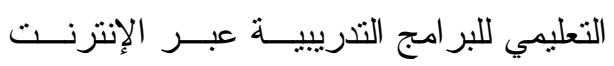

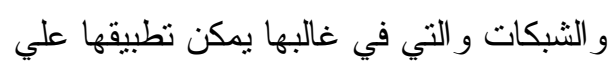

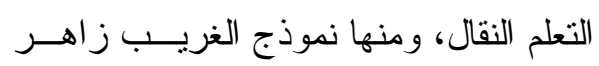

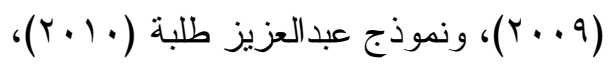

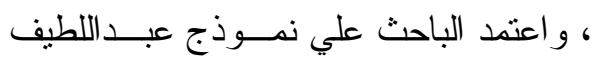

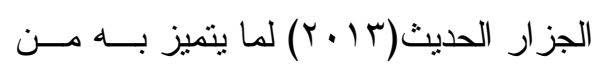
الحداثة.

\section{الإجرائات المنهجية للبحث}

في هذا الفصل يتتاول الباحث مجموعة

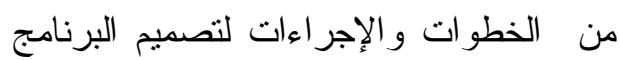
التدريبي القائم علي تكنولوجيا الأجهزة النقالة لتتمية مهار ات تـشغيل و اســتخدام الـسبورة التفاعلية لدي معلمي المرحلة المتوسطة بدولة

$$
\text { الكويت. }
$$

أولا: إعـــداد قائمــة بمهــار ات إدارة

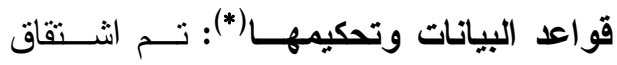

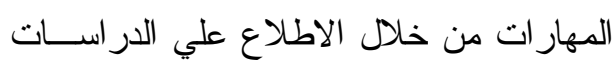

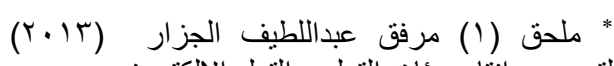
لتصميم و إنتاج بيئات التعليم و التعلم الإلكتروني . * ملحق (r) قائمة مهار ات إدارة قو اعد البيانات.
الويب وفق الوقت الزمنى و أنماط التفاعـلـل بين المدرب و المتدرب وفقاً للآتى:-

1 - التدريب الإفتراضى المتزامن: يكون

التعلــيم نز امنــي (Synchronous) وينطلب التواجد في الوقت ذاته ويتم

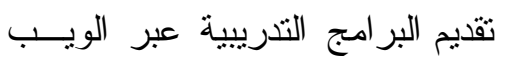
لتوصيل وتبادل الخبرات، و الأبحاث بين المدرب و المتدرب فــي نفـس ولس ولس الوقت الفعلــى للتــدريب ( David .(Wendy2002, 239 r - التدريب الإفتراضى غير المتــز امن Asynchronous لا يشترط تو اجد المدرب و المتـدرب في نفس الوقت أو المكان، و إنما تتاح الفرصة لكل منهما وفق إحتباجاتــه

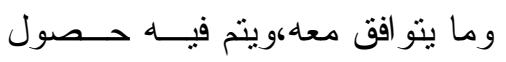

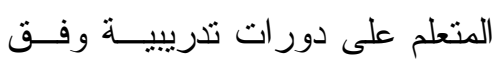

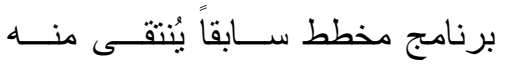

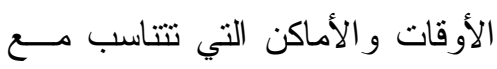

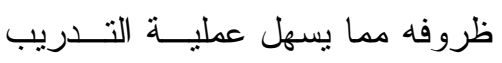

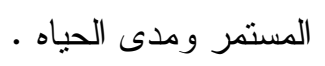
ويُعد التدريب على المهــار ات مسن

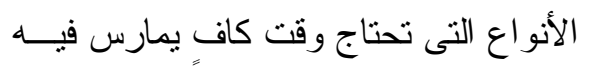

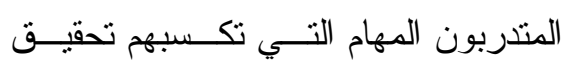
المستوى المأمول في تعلم المهار ات التـي تئي

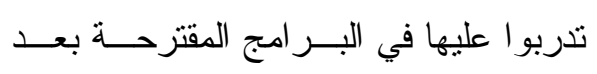

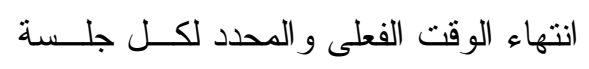


من 77 مفرده بحيث تم تقـسيمها إلـي . ؛

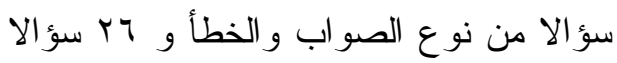
من نوع الاختيار من متعدد ، وبهـــذا تكـــون درجة الاختبار من

رابعا: إعــداد بطاقــة ملاحظـــة أداء

العينة وتحكيمها(*): قام الباحث بتصنيف بنود البطاقة ، وصياغتها ، بحيث تتضمن البطاقــة

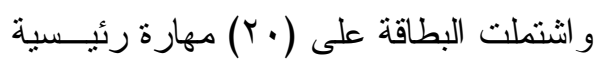

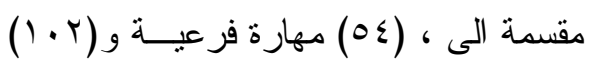
أداء متضمن بها. خامسا: التصميم التعليمي لبيئــة التـــريب الافتر اضى المقترحة: 1 - مرحلة الدراسة والتحليل: هذه المرحلة هى نقطة البدء فى عملية

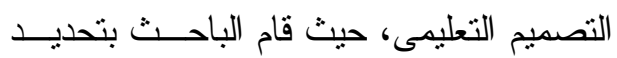

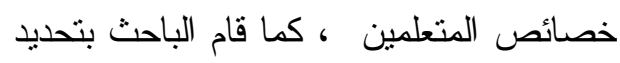

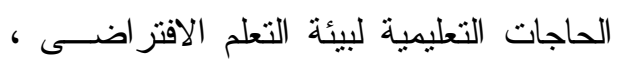

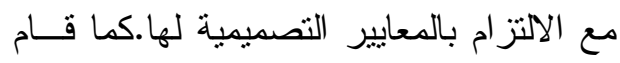

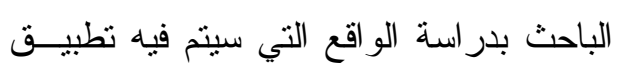

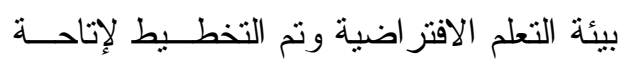

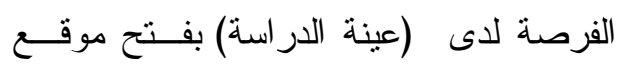
البيئة الإككتروني من أي جهاز يستخدمه سو اء

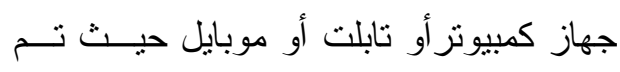

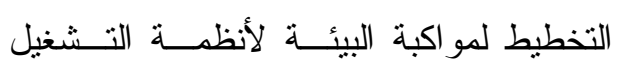

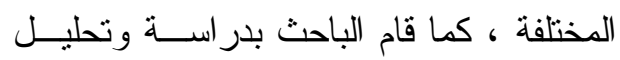

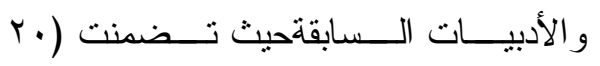
مهار ات رئيسية) و (عه إجراء فرعي)، وتم

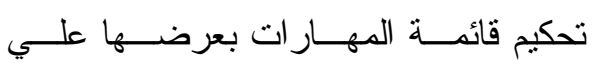

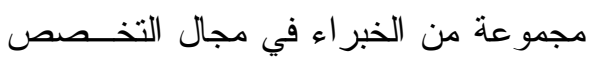
لإبداء الر أي، ثم صياغة قائمة المهار ات في صورتها النهائية. ثاتيا: إعداد قائمة بالمعاييز الواجب

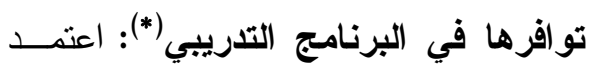
الباحث في إعداد وبنــاء قائمـــة المعـايير وصاغ الباحث مجموعــة مــن المعـايير و المؤشر ات، ثم قام بتحكيمها و عرضها علي

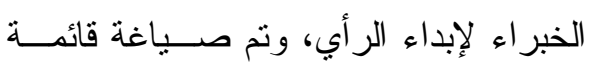

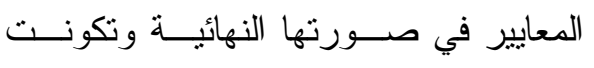

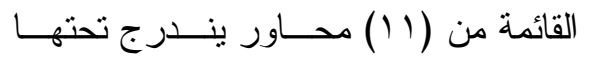

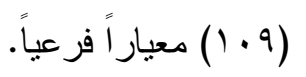
ثالثا: إعداد الاختبار التحــصيلي (*): قام الباحث بإعداد وتصميم اختبار للتحصيل

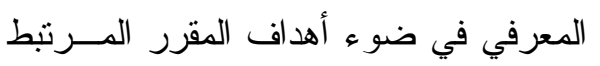

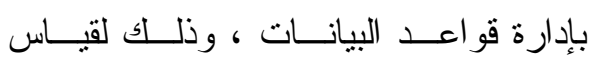
المستوي المعرفي و المهارى ومدي مناسبته

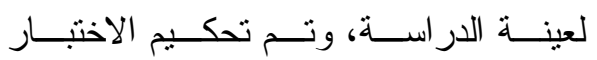
التحصيلي من قبل المحكمين و الخبر اء فـــي وني الخدي

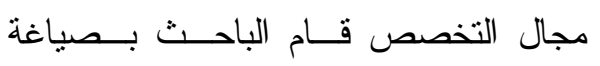
الصورة النهائية للاختبار التحصيلي المكون * ملحق (ع) الاختبار التحصيلي ونموذج الإجابة. 
خصائص البيئة لما لها من اتاحسـة الفرصــة للمتعلم في التحكم بأدو ات التعلم الخاصة به.

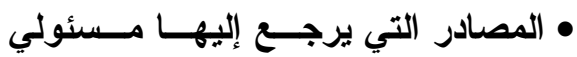
المعلومات و الاحصاء:

قام الباحث بتزويد البيئة الافتز اضــية

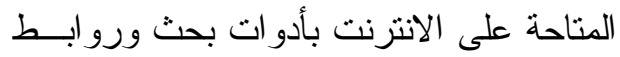
لمو اقع إلكترونية ذات صلة بمهــار ات إدارة قو اعد البيانات مثل بنك المعرفة المــصرى ، بوابة الخدمات الالكترونية الخاصة بــوزارة

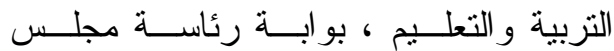

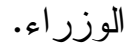
r - برحلة التصميم. هى مجموعة الإجراءات التـي قـام

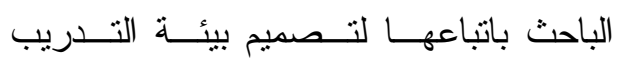

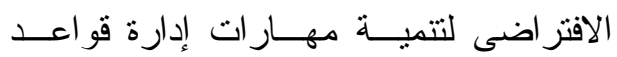

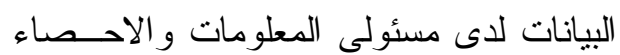
وأدوات التواصل الخاصة بها فى بيئة أوفيس لانس

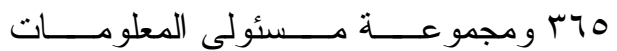

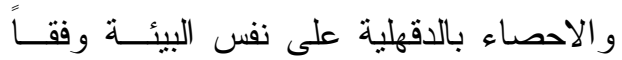

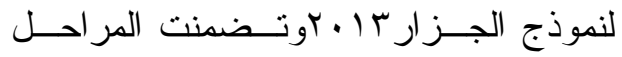

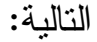

تصميم مكونات بيئة التعلم عبر الويب،

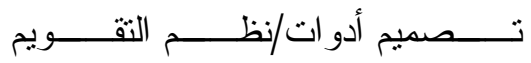

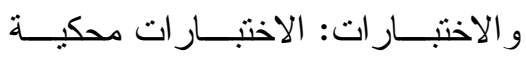
المرجع، و الاختبار ات القبلية و البعديــة التهـة للموديو لات التعليمبة أو الموضوعات التبرات الدروس التعليمية.
مصادر التعلم المتوفرة و المتعلقة بموضوع

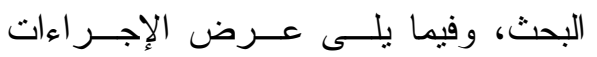

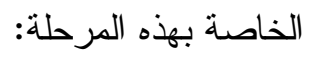
• تحليل خصائص المتعلمين:

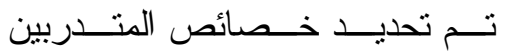

وتوصيفهم ودر اســـة حاجــاتهم التدريبيـــة وخبر اتهم العملية.

• تحديد الحاجات التعليمية للمتـدربين على بيئة التدريب الإفتراضية.

نم فى هذه الخطوة تحديد الحاجـات التعليمية للبرنامج، وذللك بمقارنــــة الو اقـــع الحالي، وتحديد هذه الفجوة (محمد عطيــة

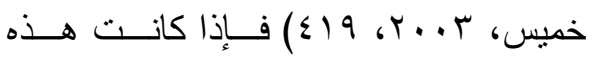
الفجوة كبيرة ظهر بوضوح مقدار الحاجـــة

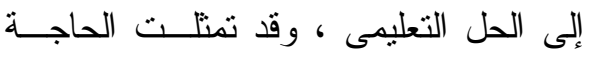

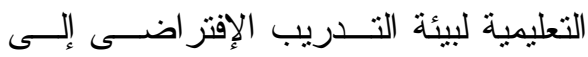

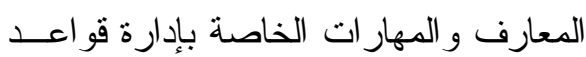
البيانات . - البعات

$$
\text { • دراسة واقـــع المــوارد والمــصادر }
$$

إن عملية الـتـعلم ببيئــة التـدريب

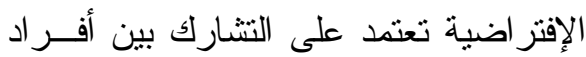
العينة وذلك بهدف تتمية المهار ات الخاصة

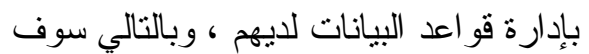

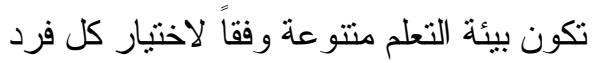

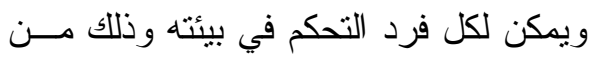


تصميم المعلومات الأساســية للبيئــة:

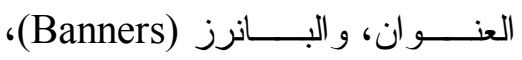

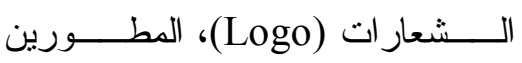

(Developers)

$$
\text { المشاركين. }
$$

\section{r- مرحلة الإنتاج والإنشاء.}

فى هذه المرحلة تم الحـصول علــى

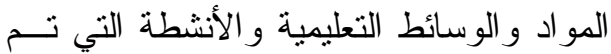

تحديدها و اختيار ها فى مرحلة التصميم، وذلك من خلال الاقتتاء من منوفر أو التعديل مـن هن منوفر أو إنتاج جديد، ثم رقمنة هذه العناصر وتخزينها، ثم تأليف البرنامج وتتفيذ السيناريو

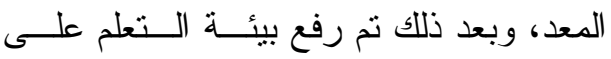
الويب ، على الموقع sayed.aimnbar.com

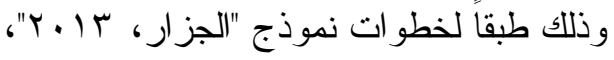
وفيما يلى خطو ات إنتاج بيئة التعلم . إنتاج معلومات وعناصر المخطط الشكلى

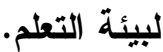

تم تحديد أنـشطة وكائنــات الــتعلم و المــصادر التعليميــة و الوســائط المتعــددة اللازمـــة لإنتـــاج موديـــولات بيئــة الــتعلم الإقتز اضية على ضوء الـسيناريو التعليهـى للبيئة و المعد سابقا؛ وذلك لافتتائها أو تعديلها

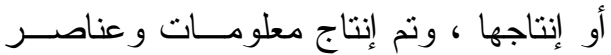

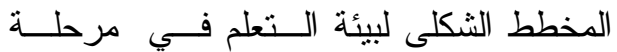

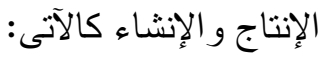

تصميم خبــرات و أنــشطة الــتعلم: المصادر و الأنشطة، تفاعلات المتعلم ذانيا أو في مجموعة التعلم معها، أو

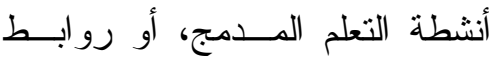

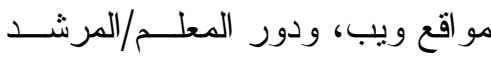
فيها لكل هدف تعليمي. تــــــميم الرســـــالة/المحتـــــــي

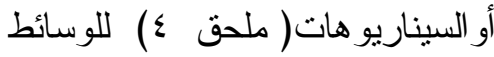
التي تم اختيار ها للمصادر و الأنشطة. تصميم أساليب الإبحار ( ملحق 0) ، و التحكم التعليمي، وو اجهة المتعلم.

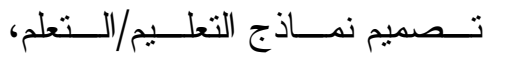
أومتغير ات التصميم، نظريات التعلم،

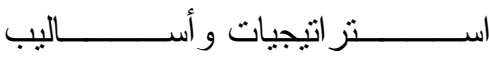

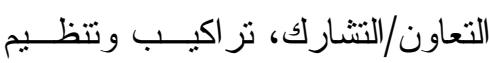
المحتوي و الأنشطة و إدارتها، أحداث

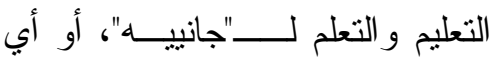
مستحدثات تصميمية.

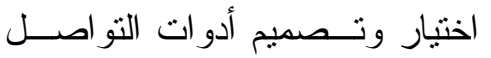

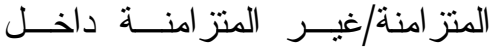

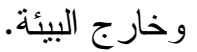

تصميم نظم تسجيل أفــر اد العينــة،

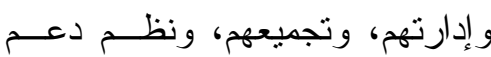
المتعلمين بالبيئة. تصميم بيانات ومعلومات و المخطط الثكلي (Layout) لعناصر البيئــة:، 
التطبيق القبلي و التطبيــق البعـــي للاختبــار

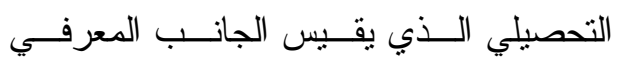

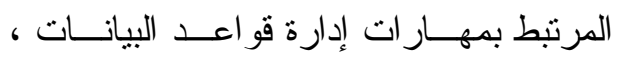
وكذلك بالنسبة لبطاقة الملاحظة (في التطبيق

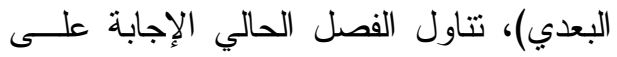

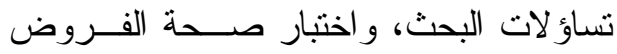

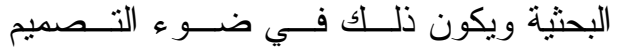

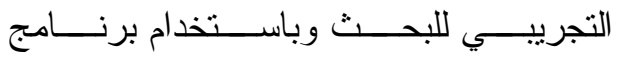

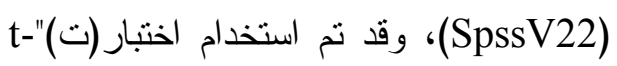
"test لتحديد دلالة الفروق بين المجموعـات

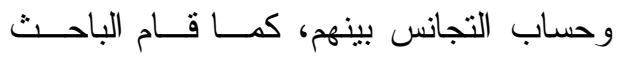

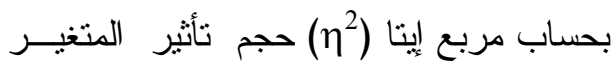
المستقل في المتغير التابع كما يلى لئ

أولا: الإجابة عن أسئلة البحث الفرعية: حيث قام الباحــث بالإجابــة علــى الأســــلة الفرعية للبحث كما يلي:

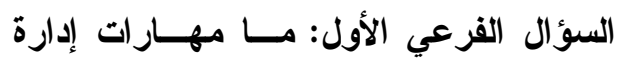

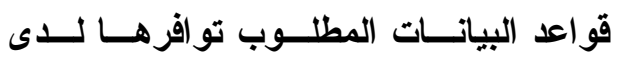

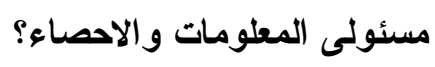

قام الباحــث بالتوصـــل إلــى قائمـــة بمهار ات إدارة قو اعد البيانات وذلك من خلال

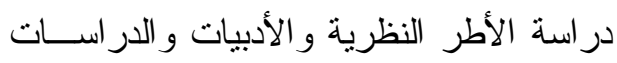

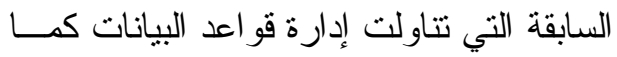

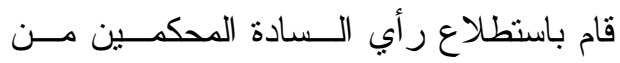

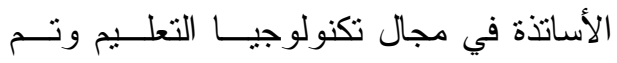

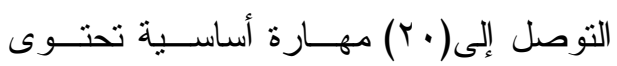

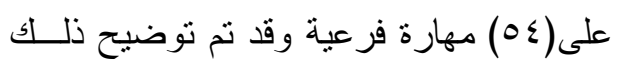

1- كتابة النصوص: تم استخدام برنامج

Microsoft Word 2010 جميع النصوص الخاصــة بالمقدمــة،

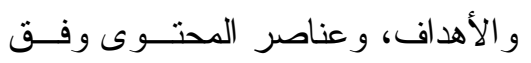
المعايير التصميمية. r - الصور الثابتة: تم الحــصول علـى الصور الثابتة التي تحتاج إليها البيئـــة من خلا محركات بحث الصور على شبكة الإنترنت.

ع - لقطات الفيــديو الرقميــة: ( DVC

\section{(Digital Video Capture}

تسجيل لقطات الفيديو التعليمية الرقمية الخاصة بيئة التعلم باستخدام برنـامج .Snagit v10

ه - إنتاج النموذج الأولي لبيأسـة الــتـطم

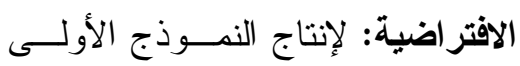

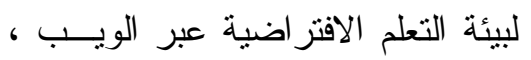

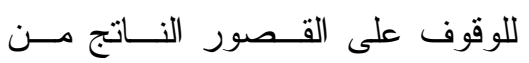
تصميم البيئة ولعمل التعديلات اللازمة للاتحون

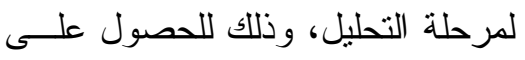

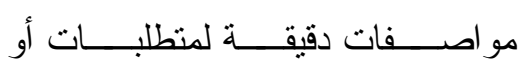
احتياجات تطوير البيئة الإلكترونية، ثم لثمات تحسين جودة عملية التصميم فى ضوء المعايير التصميمية. تتائج البحث و توصياته ومقترحاته بعــد عــرض إجــر اءات البحـــث

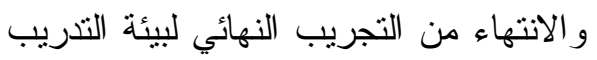
الافتز اضى ، ورصد درجات الأعضاء فــي لأني 
التعليمي حيث يتلاعم مع مـستحدثات الــتعلم

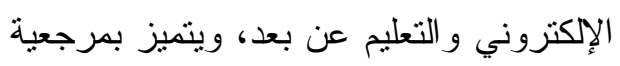

التغذية الراجعة ، و الالتز ام بالجودة الــشاملة ولئة

السائدة ، ثم التوصل إلي تصور مقتر ح لبيئــة

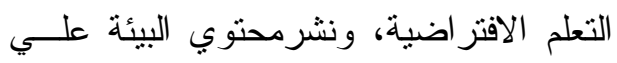

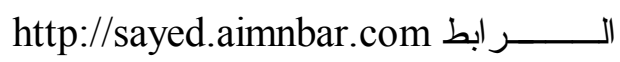

وللإجابة على الــسؤ الين الفــرعيين الرابــع

و الخامس من أسئلة البحث قام الباحث باختبار

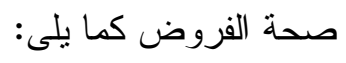
ثانياً: اختبار صحة الفروض:

وقد صاغ الباحث ثلاثة فروض لقيـاس إسبار

فاعلية بيئة التدريب الافتر اضى كما يلي:

ا- اختبار صحة الفــرض الأول: ونــــهـ :

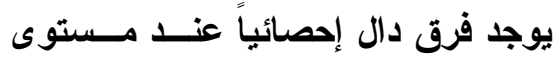

دلالة (ه . , ·) بين متوسطي كسب أفراد

المجموعة التجريبية الأولى (بيئة تدريب

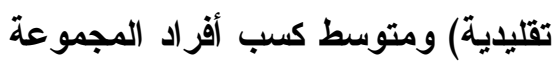

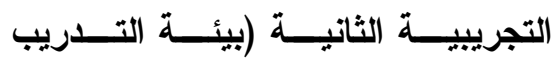

الافتراضي) في التطبيق البعدي للاختبار

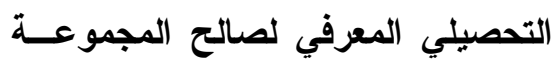

التجريبية الثانية وللتحقق من صحة هذا

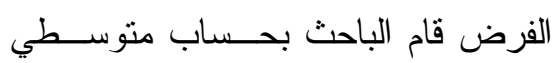

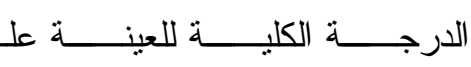

الاختبار التحصيلى و الانحر اف المعيــاري لـاني

و الفرق بين المتوسطين البعدي و القبلــي

وقيمة(ت) ودلالتها الإحصائية، و الجدول

التالي يوضِّحُ ذلك:
في الفصل الثالث الخــاص بــالإجر اءات،

وقائمة المهار ات ملحق(ب).

السؤال الفرعي الثاني :ما المعايير اللازمة

لتصميم بيئة التدريب الافتر اضــى لتنميــة مهارات إدارة قواعد البيانات لاى مسئولى لئه المعلومات والاحصاء؟

قام الباحث بالتوصــل إلـى قائمـــة

بمعايير نربوية وفنية لتصميم اســتر اتيجية

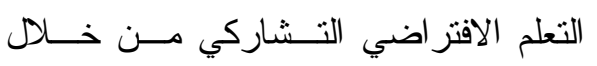
دراسة الأطر النظرية والأدبيات و الدر اسات السابقة التـي تتاولــت معــايير التــصميم الإكترونى لبيئات التعليم و التـريب القـائم على الويب، وكـــلك المعــيير الخاصـــة بالمقررات الإككترونية، وأيــضاً المعـايير

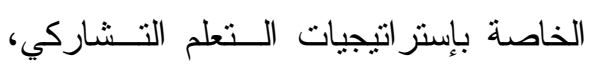

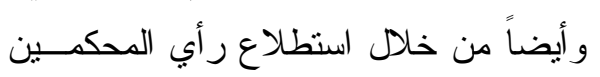
من الأساتذة في مجال تكنولوجيا التعليم، وقد

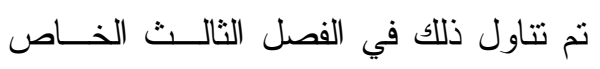
بالإجر اءات، وقائمة معسايير إســتر اتيجية

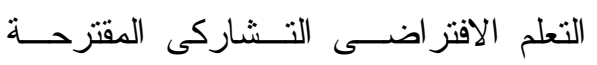

ملحق(r).

السؤال الفرعي الثالث: ما التصميم التعليمي لبيئة التدريب الافتراضى المقترحة؟

للإجابة عن هذا السؤال قام الباحـــث

بدر اسة وتحليل مجمو عة من نماذج التصميم

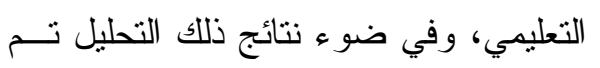

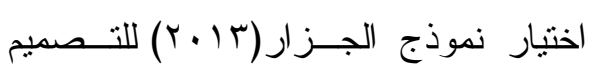




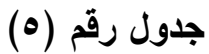

متوسط درجات العينة في الاختبار التحصيلى والاتحر اف المعياري قبليا وبعديا، والفرق بين

المتوسطين وقيمة (ت) ودلالتها الإحصائية

\begin{tabular}{|c|c|c|c|c|c|c|c|}
\hline مستوى الدلالة & قيمة (ت) & الحرجية & الالحعر افي & المتوسطين & المتوسط & العدد & التطبيق \\
\hline 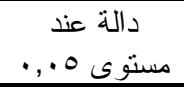 & $1 \leqslant, \pi 1 \wedge$ & $r \varepsilon$ & $\begin{array}{l}\text { r, rOY YII } \\
\text { r, ETrOA }\end{array}$ & $7, \cdot Y \wedge \uparrow$ & $\begin{array}{l}r Y, q) \leqslant r \\
\mid 7, \wedge \wedge \circ V\end{array}$ & 7. & بقبلى \\
\hline
\end{tabular}

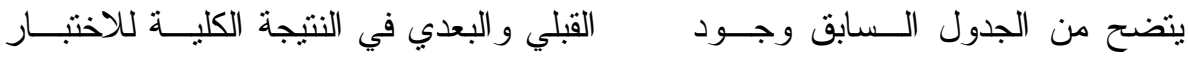

فروق ذات دلالة إحـصائية عنــد مسستوى التحصيلى لصالح النطبيق البعدي.

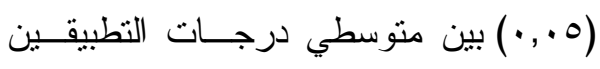

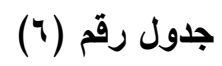

متوسطات درجات العينة في الأهداف والاتحر افات المعيارية قبليا وبعديا، والفروق بين

المتوسطات وقيمة (ت) ودلالتها الإحصائية.

\begin{tabular}{|c|c|c|c|c|c|c|c|}
\hline مستوى & قيمة & الحرية & الالحعراف & المتوسطين & المتوسط & التطبيق & الهـف \\
\hline مستوى د. . . . & $0, r 4 \Lambda$ & $T \varepsilon$ & $\begin{array}{l}\cdot, 7 \leqslant 071 \\
1, .1 \ldots r\end{array}$ & $\cdot, 9 \vee \backslash \leqslant$ & $\begin{array}{l}\text { T,YYAT } \\
\text { r,YOVI }\end{array}$ & قبلي & في نظم قو اعد البيانات المول \\
\hline مستوى 0 ـ. , . & $V, r V T$ & $r \varepsilon$ & $\begin{array}{l}\text { 1, rVqTY } \\
\text { 1,OY\&. }\end{array}$ & $r, Y) \leqslant r$ & $\begin{array}{c}1 \cdot, v \leqslant r \\
9 \\
\Lambda, \cdot r \wedge t\end{array}$ & قبلي & المو اعد البيانات الثاني إدارة \\
\hline مستوى 0 . , . & $\varepsilon, 79 \varepsilon$ & r & $\begin{array}{l}1, \leqslant r \leqslant Y A \\
1, r 1909\end{array}$ & $1,\{0 \times 1$ & $\begin{array}{l}Y, \cdot Y \wedge T \\
\varepsilon, O Y \backslash \leqslant\end{array}$ & قبلي & 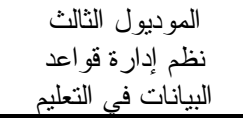 \\
\hline مستوى 0 ـ., . & $r, q 7$. & $\Gamma \varepsilon$ & $\begin{array}{l}1, \cdot 9 \leqslant 7 \wedge \\
\cdot, 9 \wedge \leqslant \vee 7\end{array}$ & $\cdot, \wedge \wedge \circ \vee$ & $\begin{array}{l}r, q 1 \leqslant r \\
r, \cdot r \wedge T\end{array}$ & قبلي & الموديول الر ابع برنامج \\
\hline
\end{tabular}

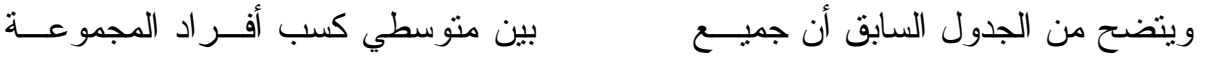

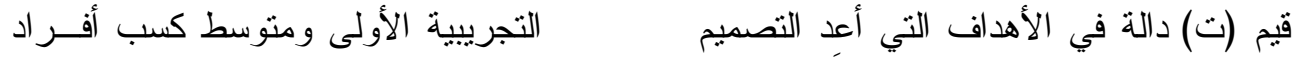

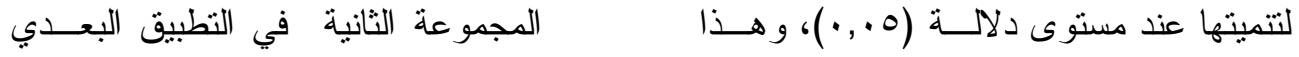

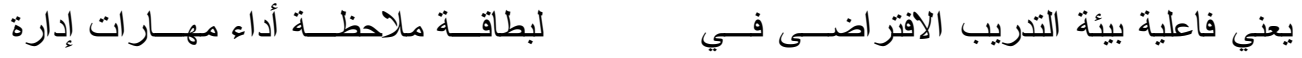

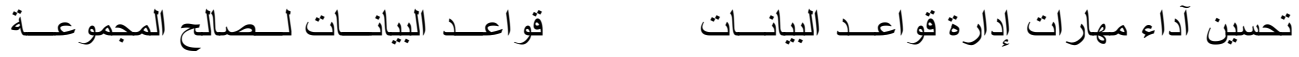

لاى أفراد العينة. التجريبية الثانية وللتحقق من صحة هذا

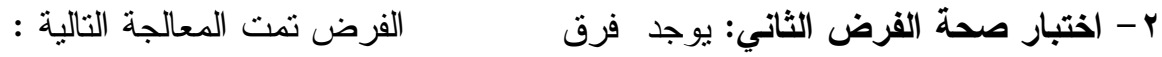

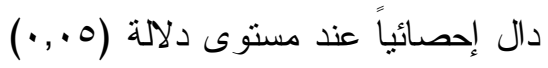


و القبلي وقيمة (ت) ودلالتها الإحــصائية

أ-حساب منوسطي الدرجة الكلية للعينــة

كما يلى: واليكي

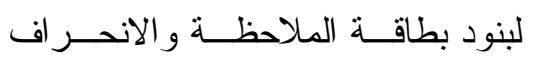

المعياري و الفرق بين المتوسطين:البعدي

جدول رقم (V)(متوسطات درجات العينة في بنود بطاقة الملاحظة والاتحر افات المعيارية قبليا

وبعديا، والفروق بين المتوسطات وقيمة (ت) ودلالتها الإحصائية

\begin{tabular}{|c|c|c|c|c|c|c|}
\hline مستوى الدلالة & قاتة) & الالانحر اف & المتوسط & التطبيق & ن & البنود البن \\
\hline مستوى دالة عـد. & $\varepsilon, 7.0$ & $\begin{array}{l}\text {. or } 9 \text { Y } 9 \\
\text {, vror } 9\end{array}$ & $\begin{array}{l}1,7 \wedge 0 \mathrm{~V} \\
1, .0 \mathrm{~V}\end{array}$ & قبلئي & 7. & 1 - فتح برنامج اكسيس • 1 · T \\
\hline مسنوى دالة ع. ., & r,orA & $\begin{array}{l}\cdot, \pi) \cdot \wedge r \\
\cdot, 0 \wedge \leqslant 1 .\end{array}$ & $\begin{array}{l}1,0 \leqslant r q \\
1, r \ldots .\end{array}$ & قبلىي & 7. & r- انثاء قاعدة بيانات \\
\hline مسنوي 0. ه. ., & r,Y YV & $\begin{array}{l}\cdot, 0 . Y) . \\
., T \mid \vee T V\end{array}$ & $\begin{array}{l}1,0 \vee 1 \leq \\
1,|\vee| \varepsilon\end{array}$ & قبلىي & 7. & r- التحكم في قاعدة البيانات \\
\hline مستوى هـ ـ. & 1,90 & $\begin{array}{l}\cdot, 09110 \\
.74 ו 1 / 4\end{array}$ & $\begin{array}{l}, 9 \leqslant Y q \\
\cdot, 7 \wedge 0 V\end{array}$ & قبلىي & 7. & ؟ - عرض قاعدة البيانات \\
\hline مستوى دالة عند. . . & $r, v q r$ & 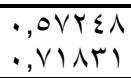 & $\begin{array}{l}l, V \backslash \leqslant r \\
1, r \mid \leq r\end{array}$ & قبلاي & 7. & ○- التحكم في النو افذ \\
\hline مستوى مالة ع. ., . & $r, \varepsilon) \varepsilon$ & $\begin{array}{l}., 091 \mu r \\
., 71099\end{array}$ & $\begin{array}{l}1, r \vee 1 \leqslant \\
1, \ldots \ldots\end{array}$ & قبلئي & 7. & 7- التعامل مع أثرطة الادوات \\
\hline مستوى هـ ـ. & $r, O \wedge \Lambda$ & $\begin{array}{l}., 0 \text { qrY } \\
., 091 \text { Y }\end{array}$ & $\begin{array}{l}1,70 V 1 \\
1, r \leq r q\end{array}$ & قبلئي & 7. & V- V- Vشاء جدول \\
\hline مستوى دالة عـ. . & r,orA & $\begin{array}{l}\cdot, 0 . Y 1 . \\
., 09 \wedge \mu r\end{array}$ & $\begin{array}{l}1,0 V I \varepsilon \\
1, Y Y \wedge y\end{array}$ & قبلئي & 7. & ي- التعامل مع الجداول \\
\hline مستوى مالة ع. ., & Y,VqV & $\begin{array}{l}\cdot, 0 Y 9 \vee 9 \\
.071 .7\end{array}$ & $\begin{array}{l}, r) \leq r \\
\cdot, 9 \vee 1 \leq\end{array}$ & قبلدي & 7. & 9 - انشاء حقل جديد \\
\hline مستوى دالة عـد. . & r,orr & $\begin{array}{l}\text {.,7. rq1 } \\
., 0 \text { q }\end{array}$ & 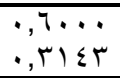 & قبلي & 7. & • 1 - تحديد المفتاح الرئيسي \\
\hline مستوى دالة عند. . . & r, Tor & $\begin{array}{l}, 7 \cdot r q 1 \\
\cdot, 7) \cdot \lambda r\end{array}$ & $\begin{array}{l}1,7 \ldots . . \\
1, \text { rovi }\end{array}$ & فبلي & 7. & 11 - التعامل مع الحقول \\
\hline 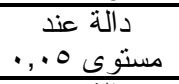 & $r, 0 . r$ & $\begin{array}{l}\cdot, V) \ldots V \\
\cdot, T \vee T I Y\end{array}$ & $\begin{array}{l}, Y \wedge O V \\
\cdot, \wedge \wedge O V \\
\end{array}$ & قبلىي & 7. & rا - ادخال سجل جديد \\
\hline مستوى 0 . ., . & r, Tor & $\begin{array}{l}\cdot, 7.491 \\
., 7.114 \\
\end{array}$ & $\begin{array}{l}1, \varepsilon \ldots \\
1,1 \leqslant r q\end{array}$ & قبلىي & 7. & זו - التعامل مع السجلات \\
\hline مستوى 0 . .,. & $r, .0 r$ & $\begin{array}{l}\cdot, \varepsilon \leqslant r \leqslant \varepsilon \\
\cdot, \vee \wedge \wedge \circ \vee\end{array}$ & $\begin{array}{l}1, V \leqslant r q \\
1, r \wedge \circ V\end{array}$ & قبلئي & 7. & ـ ا- انثاء علاقة \\
\hline مستوى 0 . ., . & $r, 0 . r$ & $\begin{array}{l}\cdot, 70 V K Y \\
., V 19 \leq \Lambda\end{array}$ & $\begin{array}{l}1, Y \circ V 1 \\
1, Y \ldots\end{array}$ & قبلىي & 7. & 0 1 - إدارة نافذة العلاقات \\
\hline مستوى دالة عـ., . & Y, 97V & $\begin{array}{l}\cdot, T \wedge \mu 0 \leqslant \\
\cdot, \leqslant \vee 1 \cdot 1\end{array}$ & $\begin{array}{l}\cdot, 70 V 1 \\
., r 1 \leqslant r\end{array}$ & قبلىي & 7. & 7 ا - انشاء نموذج \\
\hline مستوى دالة عند., . & $r, V \nearrow \leq$ & $\begin{array}{l}\cdot, 7 \leqslant 179 \\
\cdot, 70 \wedge \leq 9\end{array}$ & $\begin{array}{l}1, \cdots \\
.01 \leqslant r\end{array}$ & قبلي & 7. & V lv - إدارة النماذج \\
\hline 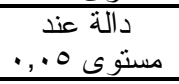 & $r, .0 r$ & $\begin{array}{l}\cdot, \varepsilon \leqslant r \leqslant \varepsilon \\
\cdot, \vee \wedge \wedge \circ \vee\end{array}$ & $\begin{array}{l}1, V \leqslant Y q \\
1, Y \wedge O V\end{array}$ & قبعدي & 7. & 1 ا - الاستعلامات \\
\hline مستوى دالة عـ. .. & r, TOY & $\begin{array}{l}\cdot, 7.491 \\
., 7.1114\end{array}$ & $\begin{array}{l}1, \leqslant \ldots \\
1,1 \leqslant r q\end{array}$ & قبلي & 7. & 9 1 - انشاء تقرير \\
\hline مسنوى 0 . ., . & $r, v q r$ & $\begin{array}{l}, 0 . Y 1 . \\
., 09 \wedge r र\end{array}$ & $\begin{array}{l}, r \mid \leq r \\
., 9 \vee \backslash \leqslant\end{array}$ & بعدي & 7. & • • إد- إدة الثقارير \\
\hline
\end{tabular}


وفيما يلي عرض نتائج هذه البيانات:

جدول رقم (^)

\begin{tabular}{|c|c|c|}
\hline \multicolumn{3}{|c|}{ حجم تأثير التصميم } \\
\hline حجم التأثير & إيتا' & ت \\
\hline كبير & ד & $1 \leqslant, \pi \mid 1$ \\
\hline
\end{tabular}

يتضح من الجدول السابق رقم (^) أن

قيمة حجم التأثير الكلي لإســتر اتيجية الــتعلم

الافتز اضى التشاركي المقترحة و المقدمة في لإني

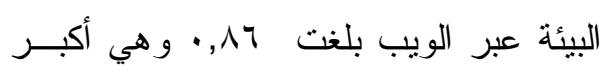
بكثير من القيمة المعيارية (ع ا, •) مما بــدل

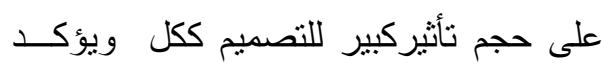
على فاعلية الاستر اتيجية في تتمية الجانسب لئب المعرفى لدى مسئولى المعلومات و الاحصاء.

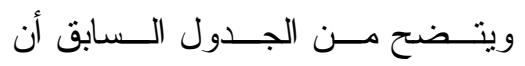
المجموعة التجريبية أبدت تحسنا في مستوى الأداء في التطبيق البعدي عنه في التطبيــق القبلي في جميع المهار ات الخاصـــة بـــإدارة قو اعد البيانات . r- اختبار صحة الفرض الثالث : و الذي ينص علي" تحقق بيئة التــدريب

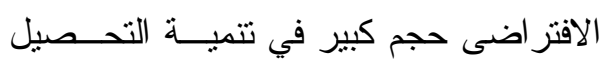

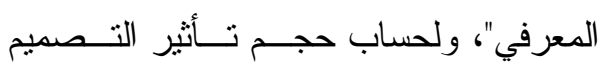

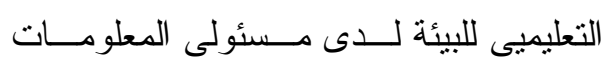
و الاحصاء استخدم الباحث (مربع إيتـا

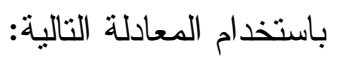

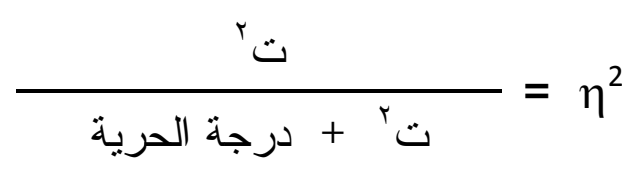

جدول رقم (9) جله

حجم تأثثر كل هدف رنم

\begin{tabular}{|c|c|c|c|}
\hline حجم التأثير & إيتاء & $ت$ & 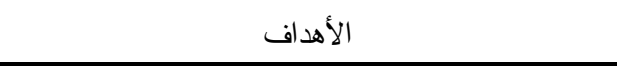 \\
\hline كبير & $\cdot, \leqslant 4$ & 0, rฯ1 & الموديول الأول مقدمة في نظم قو اعد البيانات \\
\hline كبير & י & $V, r V V^{\prime}$ & الموديول الثاني إدارة قو اعد البيانات ودعم اتخاذ القرار \\
\hline كبير & $\cdot, r q$ & $\varepsilon, 79 \varepsilon$ & الموديول الثالث نظم إدارة قو اعد البيانات في التعليم \\
\hline كبير & 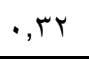 & r,97. & الدوديول الر ابع برنامج الإدارة الالكترونية للتعليم \\
\hline
\end{tabular}

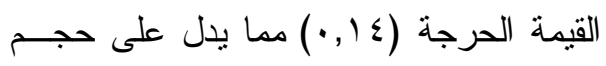

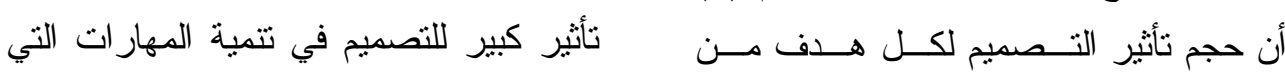

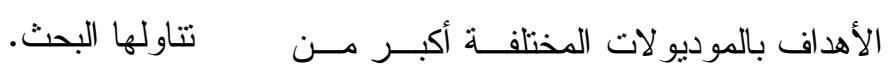




\section{جدول رقم (· (1)}

حجم تأثير التصميم في كل مهارة من المهارات على حدة جدول

\begin{tabular}{|c|c|c|c|}
\hline حجم التأثير & إيتا & $ت$ & المه \\
\hline كبير & 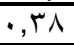 & $\varepsilon, 7,0$ & 1- فتح برنامج اكسبس • . .r \\
\hline كبير &., 17 & Y,OYA & ب- انثاء قاعدة بيانات \\
\hline كبيز & $\overline{\cdot, \mathrm{TH}^{2}}$ & $r, r, V$ & r- التحكم في قاعدة البيانات \\
\hline كبير & $\cdot, \bar{r}$ & 1,90 & ع - عرض قاعدة البيانات \\
\hline كبيز & $\cdot, 19$ & r,VAY & 0- التحكم في النو افذ \\
\hline كبيز &., 10 & $\overline{r, \varepsilon) \varepsilon}$ & 7- التعامل مع أثنرطة الادو ات \\
\hline كبير &., 17 & $\overline{r, 0 \wedge \Lambda}$ & V - انثاء جذول \\
\hline كبير &., 17 & r,OYA & 1 - 1- التعامل مع الجداول \\
\hline كبير & $\cdot, 19$ & $r, V q V$ & 9- انشاء حقل جديد \\
\hline كبير &., 17 & T,OTr & • 1- تحديد المفتاح الرئيسي \\
\hline كبير & $\cdot, \mathrm{IV}$ & T,TOY & 11 - التعامل مع الحقول \\
\hline كبير &., 17 & $\overline{r, 0 . r}$ & 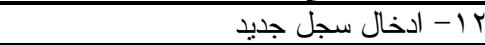 \\
\hline كبير & $\cdot, 19$ & $1, \vee \wedge 0$ & با با - لتعامل مع السجلات \\
\hline كبيز & $\cdot, Y Y$ & $r, .04$ & ع ا- انثاء علاقة \\
\hline كبير & $\cdot, 19$ & $\cdot, \leqslant 77$ & إ 10 إدارة نافذة العلاقات \\
\hline كبير & $\overline{\cdot, Y T}$ & r,97V & ا 17 - انثاء نموذج \\
\hline كبير & $\cdot, 1 \mathrm{\Lambda}$ & $\overline{Y, V \neg \varepsilon}$ & ل V Vا إدارة النماذج \\
\hline كبيز & $\cdot, \bar{r}$ & $\overline{r, Y \backslash V}$ & 11 1- الاستعلامات \\
\hline كبيز & $\cdot, 19$ & r,VAr & 19 1- انشاء تقرير \\
\hline كبير & $\cdot, r_{1}$ & $r, .0 r$ & 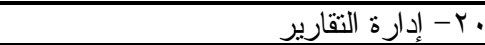 \\
\hline
\end{tabular}

أن حجم تأثير التصميم كبير في تتمية

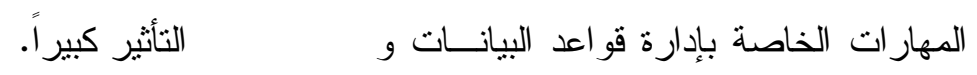

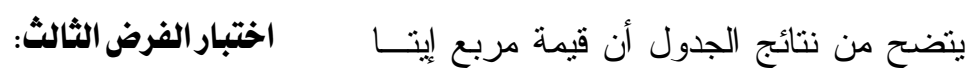

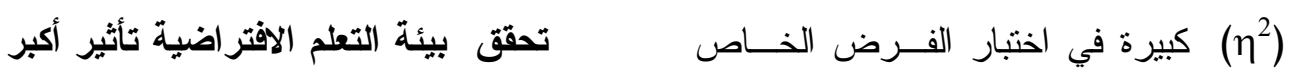
بتحقق بيئة التدريب الافتر اضى حجم كبيـر في تنمية التحصيل المعرفي.

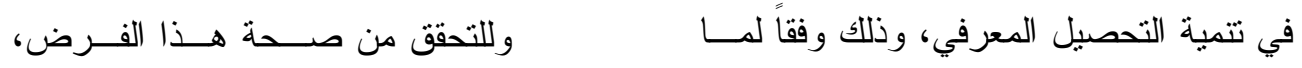

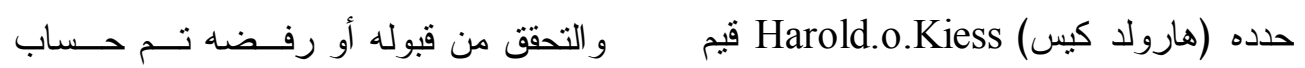

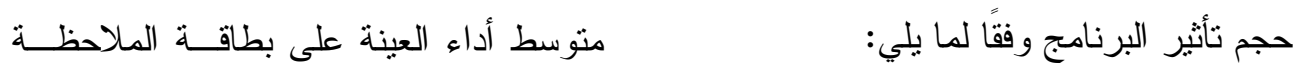

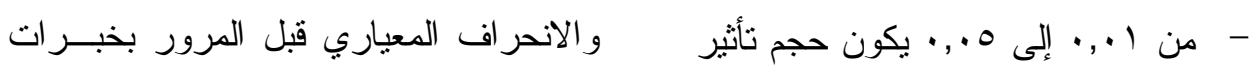

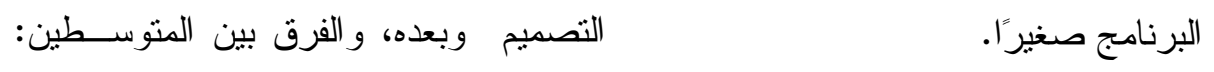

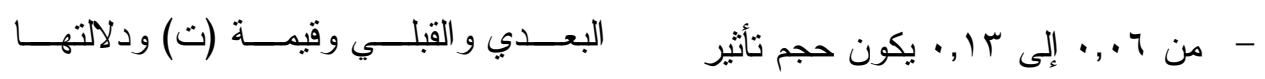
الإحصائية، كما يلي: ولي ولئ البرنامج منوسطًا. 


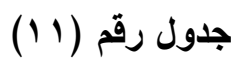

متوسط درجات العينة في الأداء التدريسي والاتحراف المعياري قبليا وبعديا، والفرق بين

\section{المتوسطين وقيمة (ت) ودلالتها الإحصائية}

\begin{tabular}{|c|c|c|c|c|c|c|}
\hline مستوى الدلالة & قيمة (ت) & درجة الحرية & فرن & الانحر اف & المتوسط & النطبيق \\
\hline \multirow{2}{*}{ مستوى 0 . , . } & \multirow{2}{*}{ rY,ON } & \multirow{2}{*}{ Tะ } & \multirow{2}{*}{$7, r \varepsilon$} & $(, 7) \varepsilon$ & $\mid r,\{Y \Lambda$ & بعدي \\
\hline & & & & $1, r \leq 7$ & $7, \cdot 17$ & قبلي \\
\hline
\end{tabular}

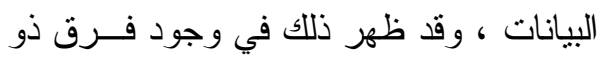
ويتضح من الجدول السابق ما يلي:

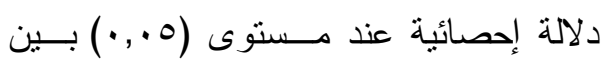
وجود فروق ذات دلالة إحصائية عند متوسطي درجات المعلمين في المجمــو عتين

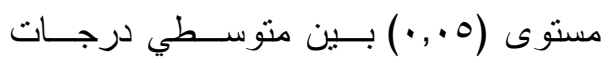

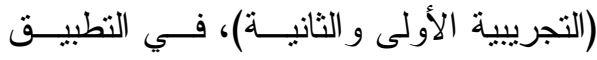
التطبيقين القبلي و البعدي في النتيجة الكليـــة بـونة البعدي في كل من: الدرجة الكلية لاختبــار

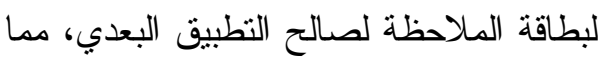
التحصيلى و بطاقة ملاحظة مهـار ات إدارة قو اعد البيانات ، وكل مهــارة علـى حــدة

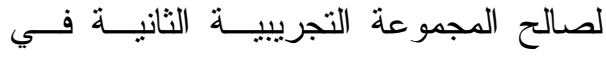
النطبيقين (القبلي و البعدي) لصالح النطبيــق يعني تحسنا ملحوظا في تتمية مهار ات إدارة قو اعد البيانات بعد مرور هم بخبر ات تصميم

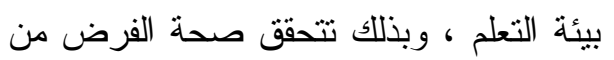
فروض البحث. وقد أعطت بطاقة الملاحظة صــورة البعدي. ويرجع الفاعلية الى : 1 - طبيعة الإستر اتيجية المقترحة وتطوير

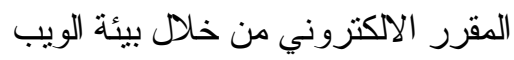
في ضوء معسـايير نكنولوجيــا الــتعلم

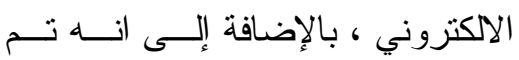

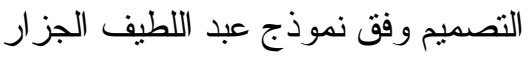

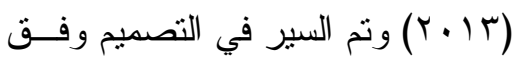
خطو ات النموذج متز امنا مـــع معــايير التصميم المقترحة . تفصيلية عن أداء العينة قبل تـصميم بيئـة

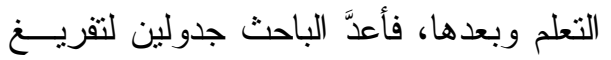
درجات المعلمين من بطاقاتهم بحيث توضع لمعاع

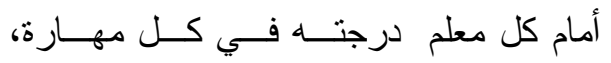

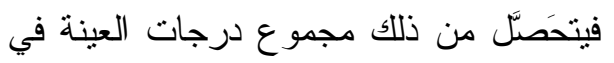
كل مهارة، وفي كل مؤشرمن مؤشر ات أداء المهارة قبليا وبعديا. تعليق عام على النتائج:

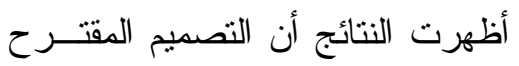
له أثز إيجابي في تتمية مهار ات إدارة قو اعد 


$$
\begin{aligned}
& \text { لإنجاز المهمة خاصة مع توفير وسائل } \\
& \text { r- نوفير مستويات متعددة ومتكاملة مسن }
\end{aligned}
$$

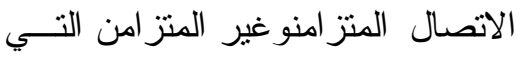

$$
\begin{aligned}
& \text { انعكست على نتائج العينة في التحصيل } \\
& \text { المعرفي وجودة التفاعلات. } \\
& \text { ع - توفير الدعم و التغذية الر اجعه من قبل } \\
& \text { المدرب في غرفة الحـــوار عبــر بيئـــة }
\end{aligned}
$$

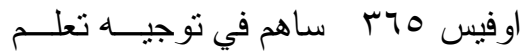

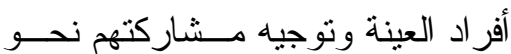

$$
\begin{aligned}
& \text { تحقيق الهدف و هذا يتفق مـــع در اســـة } \\
& \text { (Alarcon, Tutty, \& Klein, } \\
& \text { (2008 حيث هـــت الدر اســة الـى (A) } \\
& \text { الكثف عن أثز إعدادات التدريس عبــر } \\
& \text { الويب و انماط التغذية الر اجعة وتوصلت } \\
& \text { إلى فاعلية التلميحات على الأداءالمرتبط }
\end{aligned}
$$

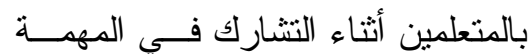

$$
\begin{aligned}
& \text { خلال التشارك في التدريس المعتمد على لئ } \\
& \text { الويب. } \\
& \text { 0- استخدام أدو ات وتكنولوجيات مجتمـع } \\
& \text { المعرفة في بيئات التشارك عبر الويب لئولي } \\
& \text { مما ساهم في تعزيز عمليــات الـتـعلم }
\end{aligned}
$$

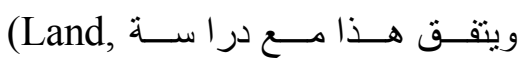

$$
\begin{aligned}
& \text { Draper, Ma, Hsieh, Jordan, \& } \\
& \text { التي أكدت علــى أن Smith, 2008) } \\
& \text { المناقتات في مجتمع الانترنت بساهم في }
\end{aligned}
$$

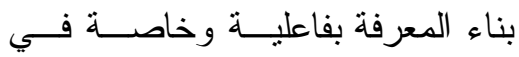

$$
\begin{aligned}
& \text { تفاعلات تحسين الأفكار ، التو اصل في وخلي } \\
& \text { مكان العمل بالمعرفة و الممارسات. }
\end{aligned}
$$

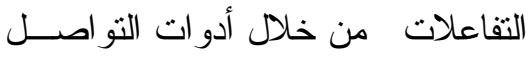

$$
\begin{aligned}
& \text { و التقاعل المتاحة المتعلقة بيئة اوفيس }
\end{aligned}
$$

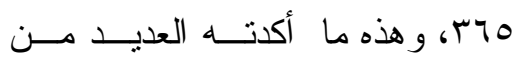

$$
\begin{aligned}
& \text { الدر اسات السابقة أن فاعلية استر اتيجيات } \\
& \text { التعلم التشاركي عبر الويب تعتمد على }
\end{aligned}
$$

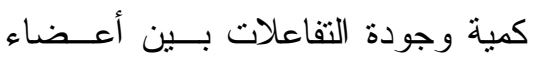

$$
\begin{aligned}
& \text { المجمو عة و هذا يتفق مع در اسة Tutty }
\end{aligned}
$$

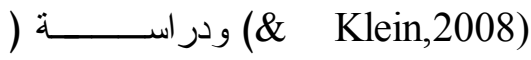




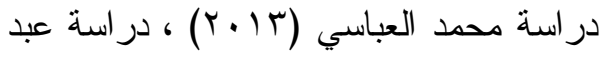

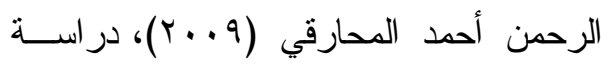

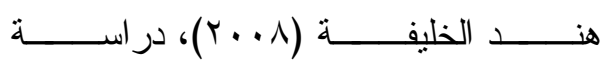

Whipp \& Dawson(2006)

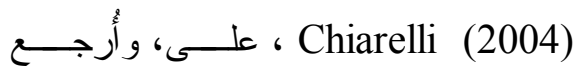
فاعليتها إلى تتوع المصادر الإكترونية الني تقدمها بيئة التعلم الإفتر اضية للمتعلمين وفي الإعني

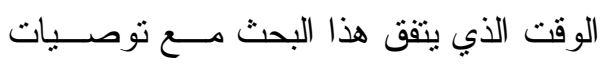

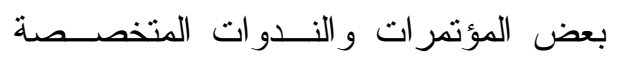
ومنها:- بعن

- مئسؤتمر جمعيــة تقنيــة التعلــيم Association of Learning Attwell, وفيــــــ أكـــ Technology Graham (2007) Blogs , Wiki, تتم في بيئة التعلم الثخصية وقد أكــدت على مركزية التعلم على المــتعلم فــي ولئ

$$
\text { المستقبل القريب. }
$$

- مؤتمر القمة العالميـــة : التقنيـــة تــــبط

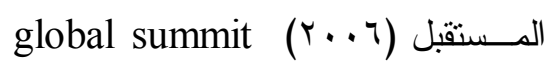
technology Connected Future الذي عقد في استر اليا ، علــى أهميــة

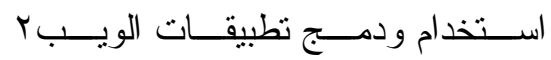
وكذلك البرمجيات الاجتماعية في بيئــة

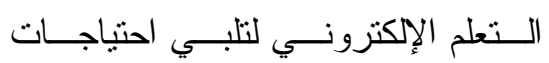
المتعلمين وفق قدر اتهم وميولهم ولتمكنهم التكروني

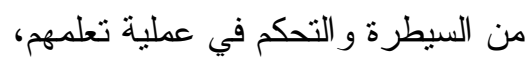

7- مر اعاة التصميم لطبيعــة وخــصائص

وسمات المعلمين المعرفية و التزبويسـة وفئة وميولهم.

V- وضـــوح أهـــداف التــصميم العامـــة

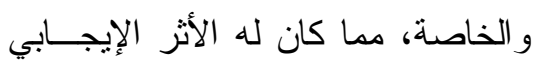
في تشجيع المعلمين على تحقيقها.

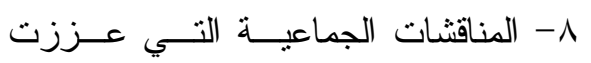

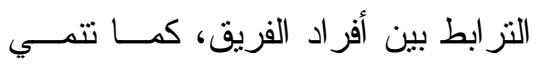

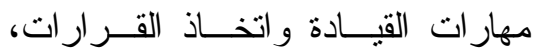
وتحول سياق الفصول الدراســية إلــى تجربة أكثر وضوحاً للمعلمين . تئرئ مناقشة نتائج البحث: تتعلق نتائج البحث في نتمية مهار ات أت إدان إدارة قو اعد البيانات باختبار الفرضين الأول لثان

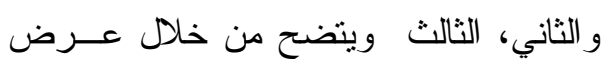

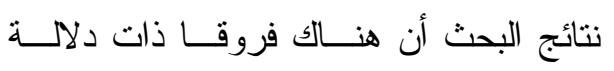

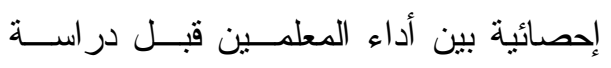
التصميم المقترح وبعد در استه على اختبــار

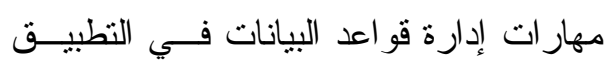

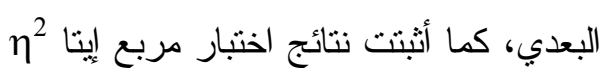

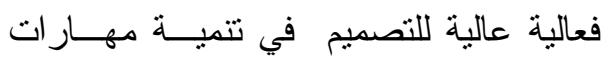

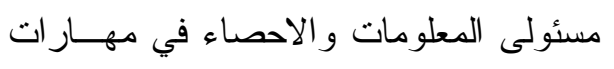
إدارة قو اعد البيانات.

وتتفق هذه النتيجة مع البحوث السابقة التي عُرِضت في هذه الدر اسة ، و التي أكََّت

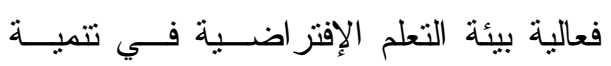
الجو انب المعرفية و الأدائية للمهار ات مثــل: 
توصيات البحث:

على ضوء نتائج البحث الحــالي، يُوصــي

$$
\text { الباحث بما بلي: }
$$

- - توظيف بيئة التعلم الافتر اضية الخاصة

بهذه الدراسة في مقررات إعداد طلاب

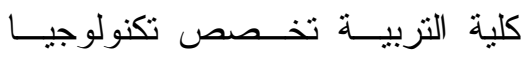

$$
\text { التعليم. }
$$

r- توظيف بيئة التعلم الافتر اضية لتتميــة

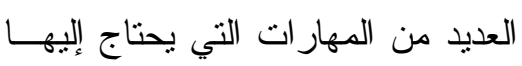

$$
\text { المعلمون. }
$$

بـ عقــــد دور ات تدريبيـــــة لمــــسئولى المعلومات و الاحصاء لتدريبهم وتتمية

$$
\text { مهار اتهم. }
$$

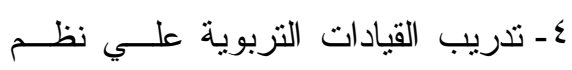

$$
\text { إدارة التعلم/التدريب الإلكتروني. }
$$

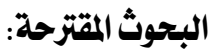

على ضوء ما توصل إليه البحث الحالي من نتائج وتوصيات، يقتر ح الباحث الموضو عات

$$
\text { البحثية الآتية: }
$$

1 - إجر اء در اســـة حــول أثــر التــدريب

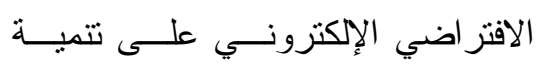

$$
\text { مهار ات القيادات التزبوية. }
$$

r- إجر اء در اسة تقويمية بهدف التعـرف

على واقــع مـستوى مهــار ات إدارة

$$
\text { التدريب الإلكترونــي لــدى القيــادات }
$$

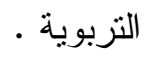

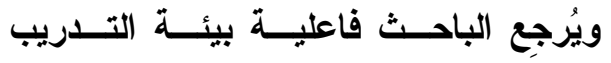

الافتر اضية للأسباب التالية:

1. ارتباط التصميم بمحاولة إيجـاد حـلـل

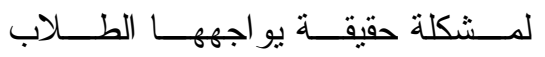

المعلمون في حياتهم اليومية، ومنطلبات

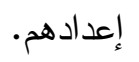

Y. وجود مهار ات جديدة بالنسبة لمسئولى

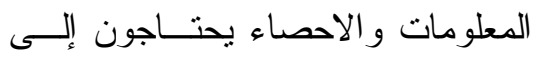

التدريب عليها دون أن يتو افر ذلك فـي

$$
\text { برنامج التدريبية المقدمة اليهم. }
$$

r. تحويل بيئة الصف التقليدية إلى المختبر

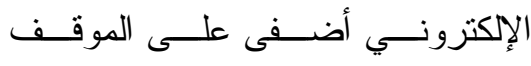

التعليمي/التذريسي جدَّة و إثارة يفتق لدها

$$
\text { الصف العادي. }
$$

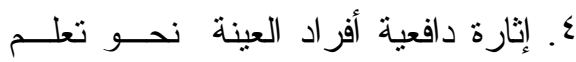

المهار ات المطلوبة نتيجـــة اســتمتاعهم

بالأسلوب الجديد المعتمد على استخدام

مستحدثات تكنولوجيا التعليم و الاتصال.

•. التصميم الفني الذي تميَّزت به البرمجية

من حيث سهولة التـشغيل، ومرونــة

القو ائم، و العرض الثائق للنصوص مما

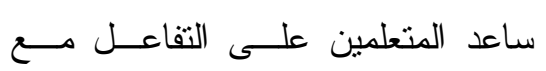

$$
\text { المحتوى. }
$$

7 ا التغذية الر اجعة الفورية التــي ينلقاهـــا

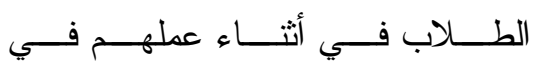

التصميم. 


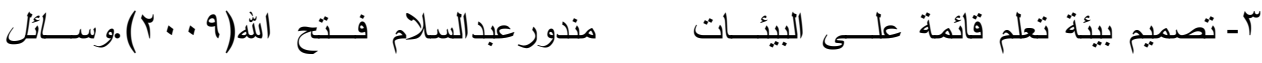

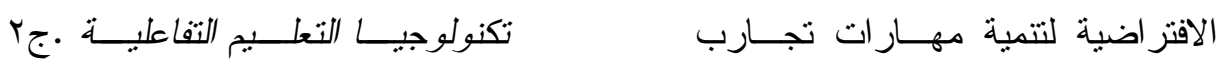

$$
\begin{aligned}
& \text { العلوم لاى الرياض:دار الصميعى. }
\end{aligned}
$$

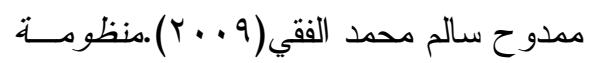

$$
\begin{aligned}
& \text { إلكترونية مقترحة لتدربيب أخــصائي } \\
& \text { تكنولوجيا التعليم على مهار ات تصديم }
\end{aligned}
$$

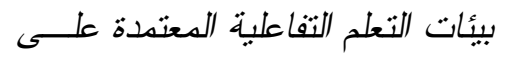

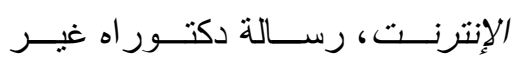

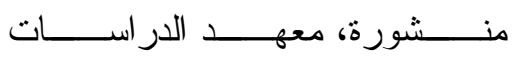

$$
\begin{aligned}
& \text { التربوية:جامعة القاهرة. } \\
& \text { محمد جابر خلف الله أحمد ( r. . r).فاعلية } \\
& \text { أسلوب التنربيس المصغر في تتميــة }
\end{aligned}
$$

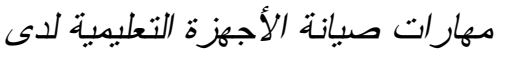

$$
\begin{aligned}
& \text { طلاب شعبة تكنولوجا التعلـــيم بكليــة } \\
& \text { التربية جامعة الأزهر ، رسالة ماجستير } \\
& \text { ، كلية التربية :جامعة الأزهر . }
\end{aligned}
$$

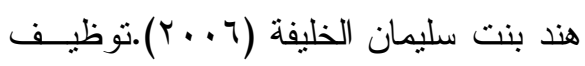

$$
\begin{aligned}
& \text { خدمات ويب r, · · في خدمة التعلــيم } \\
& \text { و التدريب الإلكتروني.المؤتمر الثقني }
\end{aligned}
$$

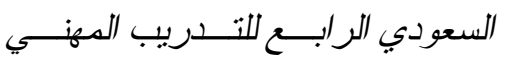

$$
\begin{aligned}
& \text { و الفني، الرياض:المملكـــة العربيــــة } \\
& \text { السعودية.. }
\end{aligned}
$$

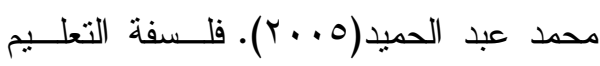

$$
\begin{aligned}
& \text { الإلكتروني عبر الثبكات ،في: محمد } \\
& \text { عبد الحميد(محرر)؛منظومة التعلــيم } \\
& \text { عبر الـشبكات .ط ا .القــاهرة:عــالم } \\
& \text { عين شمس، بr-צ }
\end{aligned}
$$


competence .Journal of Computer-Mediated

Communcation, 11(2), article.

Brown Bettina, L. (2005). Webbased Training. ERIC ED 445234.

Retrieved6,10,2010,from http://www.ericacve.org/fullt ext.asp.

Jacobson, W.(2005). Transforming a Traditional Personnel Preparation Program in Orientation and Mobility into an Online Program at the University Of Arkansas at Little Rock. JVIB, 99(11), November, 1-10.

Roger, M.\& Smith, D. (2006). Adding an Online Component to a Teacher Training Program Helps. Learning\& Leading with Technology, 33(17), February, 32-35.

David, E. S. (2002). Planning and Design for High- Technology Web Based Training. Retrieved on February, 5, 2009, from http:// books.google.com.

Land, S. M., Draper, D., Ma, Z., Hsieh, H.-W., Jordan, R., \& Smith, B. (2008). Knowledge Building Activities in an Online Community of Practice (CoP) at Subaru of America: A Case Study. The Annual Convention of the
عبد الله بن إسحاق عطــار (^ . . r).التعلــيم

$$
\text { الإلكتروني وتكنولوجيا التعليم(تدريب }
$$

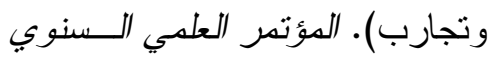$$
\text { الحادي عـشر "تكنولوجيــا التعلــيم }
$$$$
\text { الإككتروني وتحديات التطوير التربوي }
$$$$
\text { في الوطن العربي": الجمعية المصرية }
$$

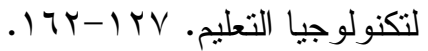

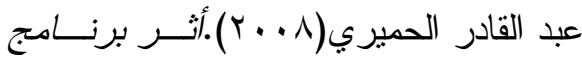$$
\text { الكتروني مقتــرح لتـــريب معلدــي }
$$$$
\text { العلوم علــى بعـض إســتراتيجيات }
$$$$
\text { التــــريب الحديثـــة،دكتـــور اه غيـــر }
$$

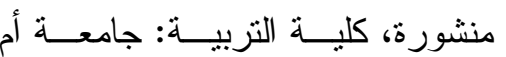

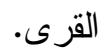

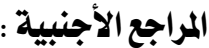

Greg, W. (2007). A Theoretical Framework for InternetBased Training at Sydney Institute of Technology. Australia. Retrieved 30,9,2010,from

http://ausweb.scu.edu.au/proc eedings/webb/paper.html.

Khan Badrul, H. (2001). WebBased Training. Educational technology publication.U.S.A.Retrieved1 ,30,2010,fromhttp:// books.google.com.

Spitzberg, B. H. (2006). Preliminary development of a model and measure of computer-mediated communication 


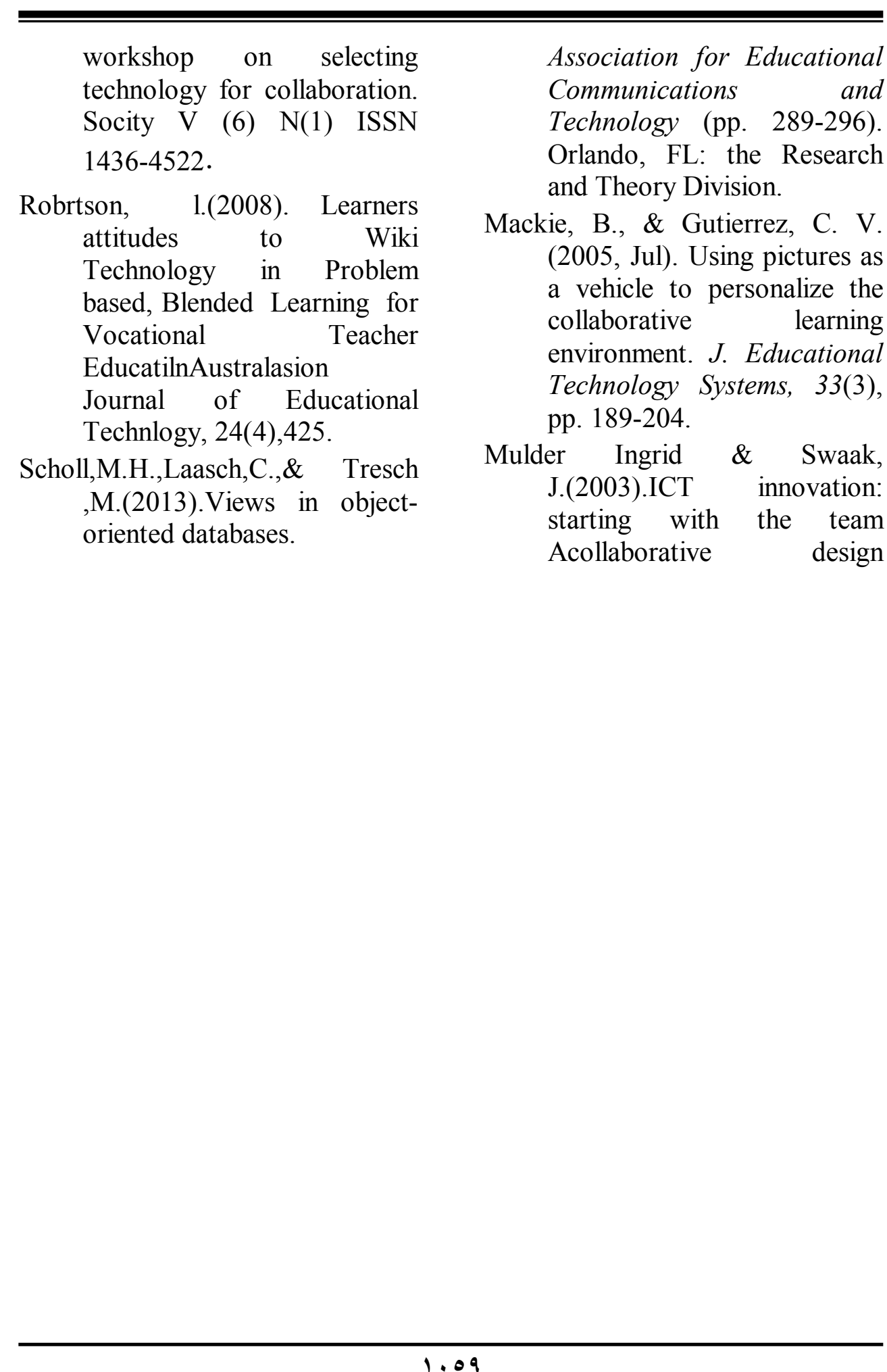

